\section{Influence of Negotiation, Glide Path, and Preflaring Procedures on Root Canal Shaping-Terminology, Basic Concepts, and a Systematic Review}

\begin{abstract}
Introduction: Negotiation, glide path, and preflaring are essential steps in root canal shaping procedures. This report aimed to discuss the terminology, basic concepts, and clinical considerations of negotiation, glide path, and preflaring procedures and the influence of these steps on root canal shaping. Methods: This systematic review was undertaken following Preferred Reporting Items for Systematic Reviews and Meta-Analyses guidelines. The protocol has been registered with the International Prospective Register of Systematic Reviews (number CRD42019127021). A comprehensive literature search was performed by 2 independent reviewers using a selected search strategy in 2 electronic databases (PubMed and Scopus) until January 28, 2019. A further search was performed manually in endodontic journals. Studies investigating or comparing at least 1 shaping property resulting from root canal instrumentation with a glide path or preflaring in human extracted teeth or clinical studies were included. Results: The literature shows that the definition of glide path and preflaring procedures remains controversial, which requires an elaboration in the American Association of Endodontists' Glossary of Endodontic Terms. After the removal of irrelevant and duplicated articles, 98 articles were included. The impact of glide path preparation and preflaring on working length determination, apical file size determination, canal transportation, separation of endodontic files, shaping time, dentinal microcrack formation, and extrusion of debris was discussed. Because of heterogeneity among the included studies, quantitative synthesis was not performed for most of the parameters. Conclusions: An evidence-based guideline is needed to define and correlate the basic concepts and current applications of each step of contemporary advancements in root canal instruments. Glide path preparation reduces the risk of debris extrusion, has no influence on the incidence of dentinal crack formation, and improves the preservation of the original canal anatomy. The creation of a glide path may have no impact on Reciproc files (VDW, Munich, Germany) in reaching the full working length. Preflaring increases the accuracy of working length determination. Further randomized clinical trials are required to evaluate the effect of a glide path and preflaring on root canal treatment outcomes. (J Endod 2020; $\mathbf{\square}: 1-23$.
\end{abstract}

\section{KEY WORDS}

Glide path; negotiation; preflaring; systematic review

Adequate knowledge and thorough synthesis of the available evidence for the shaping properties of root canal instruments are important ${ }^{1,2}$. A systematic review is an analysis of the available literature and a judgment of the effectiveness of a given procedure or practice. Two recent systematic reviews discussed the kinematic effects on the shaping properties of rotary and reciprocating nickel-titanium (NiTi) instruments in vitro and discussed consistencies and possible explanations for controversies in findings related to canal transportation, centering ability, debris extrusion, and dentinal microcracks ${ }^{1,2}$.
Gianluca Plotino, DDS, PhD, * Venkateshbabu Nagendrababu, BDS, MFDS RCPS, MDS, PhD, ${ }^{\dagger}$ Frederic Bukiet, DDS, MSC, $P h D,{ }^{\ddagger \S}$ Nicola M. Grande, DDS, PhD, " Sajesh K. Veettil, MPharm, "Gustavo De-Deus, $D D S, P h D,{ }^{*}$ and Hany Mohamed Aly Ahmed, BDS, HDD(Endo), PhD*

\section{SIGNIFICANCE}

The definition of glide path and preflaring procedures remains controversial. Glide path preparation significantly reduces canal transportation and the risk of debris extrusion. Coronal preflaring increases the accuracy of working length determination and decreases the amount of debris extrusion.

From *Private Practice, Rome, Italy;

${ }^{\dagger}$ Division of Clinical Dentistry, School of Dentistry and "School of Pharmacy, International Medical University, Kuala Lumpur, Malaysia; ${ }^{\ddagger}$ Aix Marseille University, CNRS, ISM, Inst Movement Sci and ${ }^{\S} \mathrm{APHM}$, Hôpital Timone, Service d'Odontologie, Marseille, France;

"Catholic University of Sacred Heart, Rome, Italy; "Department of Endodontics, School of Dentistry, Grande Rio University (UNIGRANRIO), Rio de Janeiro, Brazil; and ${ }^{* \star}$ Department of Restorative Dentistry, Faculty of Dentistry, University of Malaya, Kuala Lumpur, Malaysia

Address requests for reprints to $\mathrm{Dr}$ Gianluca Plotino, Private Practice, Via Calabria, 25, Rome 00187, Italy. or Dr Hany Mohamed Aly Ahmed, Department of Restorative Dentistry, Faculty of Dentistry, University of Malaya, 50603 Kuala Lumpur, Malaysia.

E-mail addresses: endo@gianlucaplotino. com or hany_endodontist@hotmail.com 
Negotiation, glide path preparation, and preflaring are essential preliminary steps in optimizing root canal shaping. These steps aim to allow for effective and safe root canal shaping and guarantee that the root canal is sufficiently enlarged to receive the first shaping instrument $^{3-9}$. However, literature shows controversies in terminology and basic concepts, and studies reveal contradictory findings and recommendations related to different systems introduced into the market ${ }^{5}$. The aims of this review were

1. to discuss terminological aspects, basic concepts, and clinical considerations of negotiation, glide path, and preflaring procedures and

2. to systematically discuss experimental and clinical reports that examined the influence of these steps on root canal shaping properties.

\section{METHODS}

A comprehensive review was undertaken to discuss the terminology, basic concepts, and clinical considerations of negotiation, glide path, and preflaring procedures. A systematic review that followed the Preferred Reporting Items for Systematic Reviews and MetaAnalyses guidelines ${ }^{10}$ was undertaken to discuss the effect of these steps on root canal shaping.

\section{Registration}

The protocol has been registered with the International Prospective Register of Systematic Reviews (number CRD42019127021).

\section{Research Questions}

The following research questions for the current systematic review were designed based on the Problem, Intervention, Comparison, Outcome, Study design (PICOS) framework:

1. Does glide path preparation (I) in human teeth $(P)$ result in better root canal shaping properties $(\mathrm{O})$ compared to teeth treated without the above intervention (C) assessed from in vitro or in vivo studies (S)?

2. Do glide path systems used in manual motion (I) result in better shaping properties (O) compared to automated motions (C) in human teeth $(\mathrm{P})$ from in vitro or in vivo studies $(\mathrm{S})$ ?

3. Do glide path systems used in reciprocation motion (I) result in better shaping properties (O) compared to continuous rotation (C) in human teeth $(\mathrm{P})$ from in vitro or in vivo studies (S)?
4. Does preflaring (I) in human teeth $(\mathrm{P})$ result in better root canal shaping properties $(\mathrm{O})$ compared to teeth treated without the above intervention (C) assessed from in vitro or in vivo studies (S)?

\section{Literature Search}

The literature search was performed using the following keywords: (flaring) OR pre-flaring) OR preflaring) OR "Early coronal flaring") OR "Coronal preflaring") OR "Coronal pre-flaring") OR "Early coronal enlargement") OR "Coronal preenlargement") OR "Coronal preenlargement") OR Glide Path) OR Negotia*) OR Scout $\left.)^{\star}\right)$ AND ((root canal) OR endod $\left.)^{\star}\right)$. The PubMed and Scopus databases were searched to identify relevant studies published until January 28, 2019. Eligible studies were also searched in the references of the included studies. An additional hand search was performed in the following journals: Journal of Endodontics; International Endodontic Journal; Australian Endodontic Journal; Restorative Dentistry and Endodontics; Iranian Endodontic Journal; and Oral Surgery, Oral Medicine, Oral Pathology, Oral Radiology, and Endodontics.

\section{Inclusion Criteria}

The inclusion criteria were as follows:

1. Studies investigating at least 1 shaping property resulting from root canal instrumentation with a glide path or preflaring in comparison with instrumentation without a glide path or preflaring.

2. Studies comparing at least 1 shaping property between manual, reciprocating, and rotary glide path or preflaring systems.

3. Studies performed in extracted human permanent teeth or in vivo.

4. Studies published only in English.

\section{Exclusion Criteria}

Studies performed in training simulated resin canals or animal teeth were excluded.

\section{Study Selection Process}

Selection of studies by screening the title and abstract followed by full text assessment was independently performed by two reviewers (V.N., H.M.A.A.). Any disagreement was resolved by the third reviewer (F.B.).

\section{Meta-analysis}

A meta-analysis was performed when the authors found it difficult to come to a conclusion on a given shaping property. Missing information was obtained by contacting the corresponding author of the study. If the mean and standard deviation were not mentioned in the text or table of the published studies, the data (mean and standard deviation) were extracted from the graphs using WebPlotDigitizer (Ankit Rohatgi; https://automeris.io/WebPlotDigitizer) ${ }^{11}$. The meta-analysis was performed using STATA 15 software (StataCorp, College Station, TX). If more than 10 studies were included in a metaanalysis, a funnel plot was generated to assess the publication bias $^{12}$.

\section{RESULTS}

The initial search resulted in 1640 articles (Supplemental Fig. S1 is available online at www. jendodon.com). Removing duplicate articles resulted in 1409 articles for title and abstract screening. One hundred two articles were identified for full-text retrieval; 4 articles ${ }^{13-16}$ were excluded because the studies were not performed in human permanent teeth. A total of 98 articles were included. (Kappa analysis between reviewers showed almost perfect agreement $[\kappa=0.860])$. The retrieved articles were categorized into 2 categories:

1. glide path preparation and

2. preflaring.

No studies compared negotiation as a single procedure because it is a common step before glide path preparation and preflaring; however, the terminological aspects and basic concepts were discussed.

The shaping properties including working length (WL) determination, canal transportation and centering ability, separation of endodontic instruments, time (shaping time [ST] and glide path time [GPT]), dentinal defects/microcrack formation, extrusion of debris, and apical file size were discussed under each category.

\section{DISCUSSION}

\section{Negotiation of the Root Canal Terminology}

Exploration and scouting are synonyms of the English term negotiation. In endodontics, this term refers to the passive exploration phase of the canal using small files to appreciate the morphology and initial patency of the canal and its resistance to file penetration ${ }^{3}$.

\section{Basic Concepts}

A natural path that can be defined as "anatomic" is present in nature because it is created by the neurovascular bundle that penetrates from the apex and reaches the Raschkow plexus in the pulp chamber of the tooth. However, once the canal orifice is 
located, negotiating this path by endodontic instruments is often difficult, especially if the canal is narrow and/or curved ${ }^{7,17}$.

An adequate understanding of the pulp space configuration and its variations enables the clinician to successfully locate, negotiate, and prepare all root canals ${ }^{7,18}$. Therefore, negotiation of the root canal aims to gather as much knowledge as possible about its anatomy (size, width, narrowness, or calcification) and its geometry (orientation and curvature) without necessarily attempting to reach the working length ${ }^{19}$. Adequate understanding of these fine details is of prime importance because certain anatomic features may compromise the safety and efficacy of subsequent enlarging instruments ${ }^{8,20}$.

Negotiation of root canals is usually performed using small stainless steel (SS) K-files (or reamers) sizes 06 to 10 in a watchwinding movement ${ }^{4}$. As a general rule, smallsized instruments are suitable for calcified canals, whereas precurved instruments are suitable for abrupt canal curvatures ${ }^{6,17,21,22}$. Variations in the file design have also been considered to maximize the necessary balance between small size, increased rigidity needed for penetration, and minimal deformation, especially when used in more complex canal morphology (such as narrow curved canals) ${ }^{23}$. Previous studies showed that using magnification tools (dental loupes or preferably an operating microscope) enhances the ability to negotiate canals ${ }^{24-26}$.

\section{Glide Path Preparation \\ Terminology}

In aeronautics, when landing, a glide path refers to the approach path of an aircraft, which is typically defined by a radar beam. When an object glides to a certain direction, it moves silently and in a smooth and effortless manner ${ }^{27}$. In endodontics, the only available published definition of the glide path is a "smooth radicular tunnel from canal orifice to physiologic terminus (apical constriction)"28. However, literature shows that this definition still remains a matter of debate ${ }^{5}$, which requires an elaboration in the American Association of Endodontists' Glossary of Endodontic Terms ${ }^{29}$.

\section{Basic Concepts}

A glide path is achieved when the file can enter from the canal orifice passing smoothly along the canal walls to the apical terminus in a simple, repeatable, and predictable manner, resulting in a "super-loose" SS file size $10^{28,30}$. In some cases, the glide path can be obtained using smaller files (sizes 06 or 08 ), thus creating a sufficient space that allows a file size 10 to reach the WL.

The glide path should be maintained if it can be initially negotiated or obtained if it cannot. This will enable the successful and safer use of subsequent enlarging NiTi files because the presence of this space helps to drive the tip of the instrument on its way inside the canal ${ }^{31,32}$.

\section{Preflaring \\ Terminology}

In certain clinical situations, the presence of a glide path may be not sufficient to ensure the safe use of rotary files. Thus, an additional operating step, namely preflaring, may be indicated $^{33}$. Preflaring has been defined as a pre-enlargement of the root canal up to its terminus using hand files to a tip size at least equal to that of the tip of the first rotary instrument that will be used ${ }^{34}$.

Coronal (cervical) preflaring (early coronal flaring) and coronal pre-enlargement (early coronal enlargement) are also terms that have been used to describe the preenlargement of the coronal third (and sometimes the middle third) of the root canal before determination of the $\mathrm{WL}^{35-39}$. The main purpose of preflaring (and coronal preflaring) is to minimize the torsional stress on the file when engaging into the root canal, thus decreasing the risk of file separation ${ }^{40-43}$.

\section{Basic Concepts}

As instruments advance apically, especially in narrow canals, they tend to give their form to the canal. At this point, giving the canal a form and size similar to such instruments would further engage the instrument along the canal walls and increase the mechanical stresses. For this reason, coronal preflaring (early coronal enlargement) has been advocated to reduce the contact between the file and the dentin walls and to lessen the initial coronal curvature to gain a straight-line access to the middle and apical thirds of the canal (Fig. 1A-F). Therefore, coronal preflaring prevents iatrogenic mishaps, such as ledges, blockages, or canal transportation, and improves debris elimination ${ }^{2,44}$. In addition, this step allows for better tactile sensation of the apical constriction and diameter and enhances irrigant penetration into the apical third $^{35}$. Moreover, this step allows the instrument to maintain its prebending necessary for negotiation of abrupt canal curvatures.

Early elimination of coronal interferences can be performed with Gates Glidden (GG) burs (sizes 1, 2, or 3) or NiTi files that are specifically designed for enlargement of the canal orifice ${ }^{45}$. Early coronal enlargement should be performed with caution at the expense of the outer cavity wall away from the furcation following the anticurvature concept $^{46}$. An indiscriminate removal of coronal dentin to a diameter larger than $1 \mathrm{~mm}$ would substantially reduce the root thickness and subject the tooth to an increased risk of root perforation and treatment failure ${ }^{47}$.

Specific ultrasonic tips may be used for this purpose, which is a less invasive and more advantageous procedure in terms of visibility and control than others ${ }^{48}$.

With the introduction of the single-length instrumentation technique ${ }^{49}$ and reciprocating movement ${ }^{50}$, "selective early coronal enlargement" may be preferred. It aims to remove the coronal interferences while preparing the root canal ${ }^{37}$. This could be beneficial for negotiation and initial canal preparation of second mesiobuccal canals in maxillary molars that may have coronal canal curvatures (Fig. 1G-l). This mechanism enables limited removal of dentin in the cervical area (pericervical dentin, $4 \mathrm{~mm}$ below and above the canal orifice), which is of prime importance for maintaining reasonable strength of the endodontically treated teeth ${ }^{51-53}$. This approach also emphasizes that the access cavity preparation is dynamic during the root canal treatment procedure (Fig. 1C-F). Using a case by case strategy, the endodontic cavity can be extended or maintained in a conservative configuration taking anatomic challenges into account to reach the apical terminus safely.

Once negotiation and glide path steps are successfully performed, the extension of preflaring mainly depends on the size of the tip of the first NiTi rotary instrument to be used ${ }^{54}$. A hand SS file size 15 has more potential risks of creating iatrogenic damages in a narrow root canal compared with file size 10 because of its relative stiffness related to its dimensional increase of 50\% compared with file size $10^{55}$. Thus, file size 15 may not easily follow the glide path assured by file size 10, and its improper use could lead to the creation of ledges, blockages, and canal transportation $^{56}$. If the preflaring step should be extended to an SS hand file size larger than 10 , then using instruments of intermediate sizes (ie, sizes 12 and 17) is recommended. However, the hand and rotary/reciprocating NiTi files, which are more flexible and less likely to alter the original anatomy, are sometimes more appropriate for this purpose ${ }^{55,57}$.

It is worth mentioning that most of the rotating or reciprocating instruments commonly marketed as "glide path files" are in reality "preflaring files" because they are used 


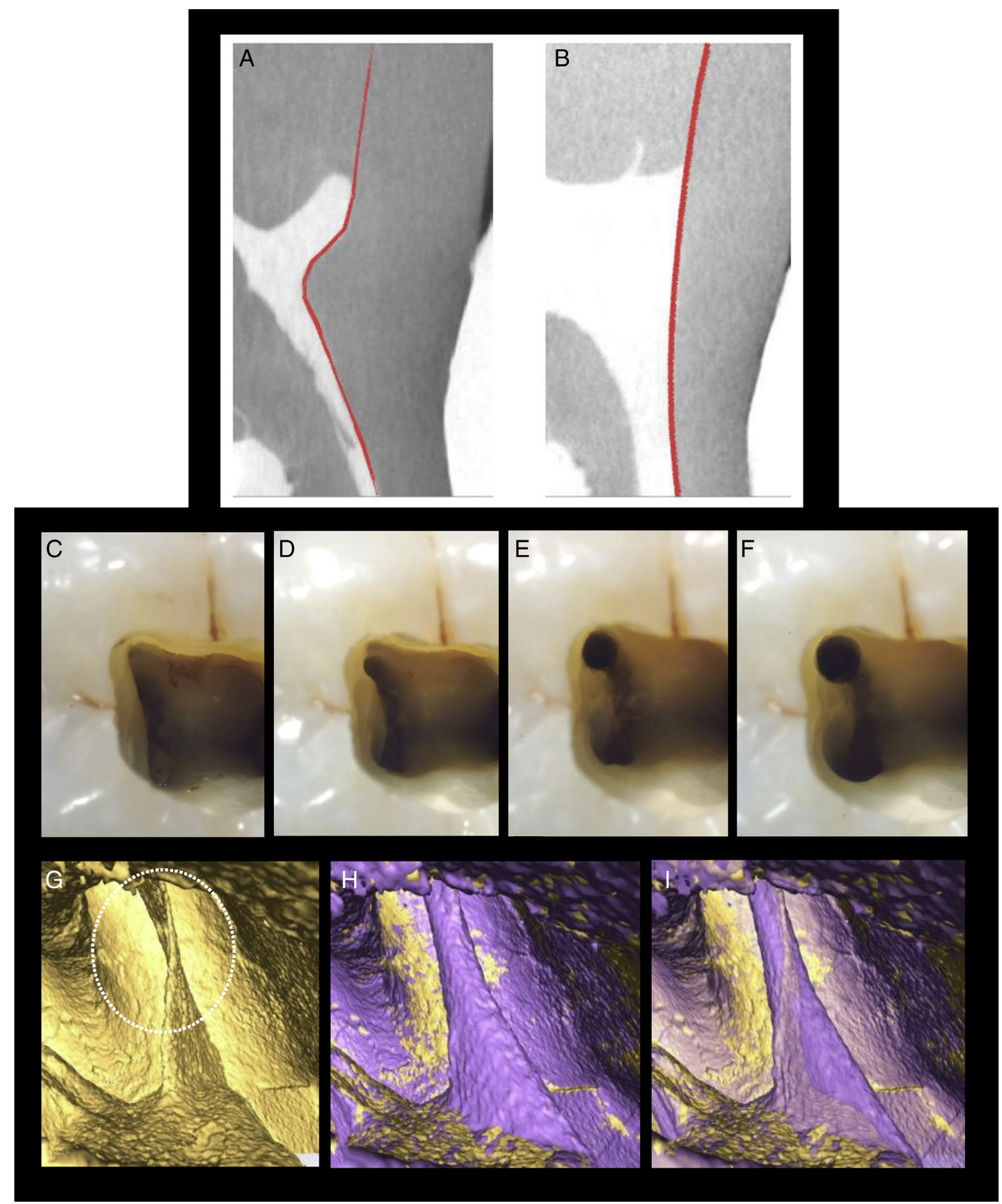

FIGURE 1 - A micro-computed tomographic scan of a mandibular molar $(A)$ before and $(B)$ after early coronal enlargement and preflaring (complete and indiscriminate removal of the dentin triangle) of 1 of the mesial root canals. Topographic views of the root canal orifice shape at different phases of root canal treatment procedures. $(C)$ The access cavity without any early coronal enlargement. $(D-F)$ Selective coronal enlargement of the orifices during root canal preparation that aims to cut only the amount of dentin needed to allow enlarging files to reach the apex safely without excessive stress. The amount of coronal interference removed is related to the root canal anatomy and the instruments used. This image also demonstrates the dynamic nature of the access cavity preparation along the treatment in which more tooth structure was selectively and progressively removed from the mesial wall. ( $G-I)$ Three-dimensional reconstructions of micro-computed tomographic scans showing the mesiobuccal root of a maxillary molar. In yellow $(G)$, the preoperative image showing the second mesiobuccal with abrupt coronal canal curvature apical to the canal orifice. In violet $(H)$, the postoperative image showing the amount of dentin removed to access the second mesiobuccal root canal highlighted by the (I) transparent image of the pre-post overlap. 
TABLE 1 - Studies Showing the Glide Path Preparations, Methods Used for Evaluation, and Conclusions

\begin{tabular}{|c|c|c|c|}
\hline Author(s), year & Comparison & Methods for evaluation & Conclusion \\
\hline $\begin{array}{l}\text { Uroz-Torres } \\
\text { et al, } 2009^{68}\end{array}$ & $\begin{array}{l}\text { Group 1: glide path using size } 8,10 \text {, and } 15 \\
\text { K-files followed by Mtwo rotary } \\
\text { Group 2: no glide path } \\
\text { Canal curvature: } 25^{\circ}-44^{\circ} \text { and } 45^{\circ}-76^{\circ} \\
\text { (mesiobuccal root canal in mandibular } \\
\text { molars) }\end{array}$ & 2D digital radiography & $\begin{array}{l}\text { Manual glide path before Mtwo did not } \\
\text { influence the apical transportation in } \\
\text { curved root canals. }\end{array}$ \\
\hline $\begin{array}{c}\text { De Oliveira Alves } \\
\text { et al, } 2012^{64}\end{array}$ & $\begin{array}{l}\text { Group 1: glide path using size } 10,15 \text {, and } \\
20 \text { K-files } \\
\text { Group 2: PathFiles } \\
\text { Group 3: MTwo rotary }(10,15,20) \\
\text { Canal curvature: } 25^{\circ}-35^{\circ} \text { (mesial root } \\
\text { canals in mandibular molars) }\end{array}$ & 2D digital radiography & $\begin{array}{l}\text { Neither the manual instruments nor the } \\
\text { PathFile or Mtwo rotary instruments used } \\
\text { to create a glide path had any influence } \\
\text { on the occurrence of apical } \\
\text { transportation or produced any canal } \\
\text { aberration. }\end{array}$ \\
\hline $\begin{array}{l}\text { Pasqualini } \\
\text { et al, } 2012^{58}\end{array}$ & $\begin{array}{l}\text { Group 1: glide path using size } 8,10,12,15 \text {, } \\
\text { 17, and } 20 \text { K-files } \\
\text { Group 2: PathFile rotary } \\
\text { Canal curvature: moderate }\left(\leq 35^{\circ}\right) \text { or severe } \\
\left(\geq 40^{\circ}\right) \text { (mesiobuccal } 1 \text { and distobuccal } \\
\text { canals in maxillary molars) }\end{array}$ & Micro-CT imaging & $\begin{array}{l}\text { PathFile instruments preserve the original } \\
\text { canal anatomy and cause less canal } \\
\text { aberrations compared with K-files. }\end{array}$ \\
\hline $\begin{array}{l}\text { D'Amario } \\
\text { et al, } 2013^{63}\end{array}$ & $\begin{array}{l}\text { Group 1: G-File rotary } \\
\text { Group 2: PathFile rotary } \\
\text { Group 3: size } 10,15 \text {, and } 20 \mathrm{~K} \text {-type files } \\
\text { Canal curvature: moderate }\left(25^{\circ}-35^{\circ}\right) \\
\quad \text { (mesial canals in mandibular molars) }\end{array}$ & 2D digital radiography & $\begin{array}{l}\text { The G-File, PathFile, and K-files did not } \\
\text { have any influence on the occurrence of } \\
\text { apical transportation nor did they } \\
\text { produce a change in the angle of canal } \\
\text { curvature. }\end{array}$ \\
\hline $\begin{array}{l}\text { Dhingra and } \\
\text { Manchanda, } \\
2014^{75}\end{array}$ & $\begin{array}{l}\text { Group 1: PathFiles } \\
\text { Group 2: V-Glide Path } 2 \\
\text { Canal curvature: }\left(20^{\circ}-30^{\circ}\right) \text { (mesial canals in } \\
\quad \text { mandibular molars) }\end{array}$ & CBCT imaging & $\begin{array}{l}\text { PathFiles resulted in more centric ability in } \\
\text { mesial canals compared with V-Glide } \\
\text { Path } 2 \text { files. }\end{array}$ \\
\hline $\begin{array}{l}\text { Elnaghy and } \\
\text { Elsaka, } 2014^{65}\end{array}$ & $\begin{array}{l}\text { Group 1: ProTaper Next } \\
\text { Group 2: ProGlider/ProTaper Next } \\
\text { Group 3: PathFile/ProTaper Next } \\
\text { Canal curvature: }\left(25^{\circ}-35^{\circ}\right) \text { (mesiobuccal } \\
\quad \text { canals in mandibular molars) }\end{array}$ & СBCT imaging & $\begin{array}{l}\text { No significant difference regarding the } \\
\text { volume of removed dentin and centering } \\
\text { ratio. At 3- and 5-mm levels, the } \\
\text { ProGlider/ProTaper Next group showed } \\
\text { a significantly lower mean transportation } \\
\text { value (no significant difference at } 7 \mathrm{~mm} \text { ). } \\
\text { The ProGlider/ProTaper Next } \\
\text { instrumentation method revealed better } \\
\text { performance with fewer canal } \\
\text { aberrations when compared with } \\
\text { instrumentation performed with PathFile/ } \\
\text { ProTaper Next or ProTaper Next only. }\end{array}$ \\
\hline $\begin{array}{l}\text { Zanette } \\
\quad \text { et al, } 2014^{69}\end{array}$ & $\begin{array}{l}\text { Group 1: PathFile/ProTaper Universal F3, } 4 \\
\text { Group 2: ProTaper F3, } 4 \\
\text { Canal curvature: }\left(20^{\circ}-35^{\circ}\right) \text { (mesiobuccal } \\
\quad \text { canals in maxillary molars) }\end{array}$ & 2D digital radiography & $\begin{array}{l}\text { The use of the PathFile system before root } \\
\text { canal preparation did not influence apical } \\
\text { transportation but was associated with } \\
\text { greater remaining dentin thickness at } 2 \\
\text { and } 3 \mathrm{~mm} \text { from the apex. }\end{array}$ \\
\hline $\begin{array}{l}\text { Dhingra } \\
\quad \text { et al, } 2015^{66}\end{array}$ & $\begin{array}{l}\text { Group 1: PathFile/WaveOne reciprocation } \\
\text { Group 2: WaveOne } \\
\text { Canal curvature: }\left(20^{\circ}-30^{\circ}\right) \text { (mesial canals of } \\
\quad \text { mandibular molars) }\end{array}$ & CBCT imaging & $\begin{array}{l}\text { The application of PathFile before } \\
\text { WaveOne improves the centric ability } \\
\text { with lesser transportation in addition to } \\
\text { increased cross-sectional area and more } \\
\text { residual dentin thickness. However, it } \\
\text { increases the difference of root canal } \\
\text { curvature. }\end{array}$ \\
\hline $\begin{array}{l}\text { Pasqualini } \\
\text { et al, } 2015^{76}\end{array}$ & $\begin{array}{l}\text { Group 1: ProGlider/ProTaper Next } \\
\text { Group 2: ScoutRace/Bio-Race } \\
\text { Canal curvature: }\left(25^{\circ}-40^{\circ}\right) \text { (mesiobuccal } \\
\text { canals of maxillary molars) }\end{array}$ & Micro-CT imaging & $\begin{array}{l}\text { Neither system produced significant } \\
\text { shaping errors in curved canals. } \\
\text { ProGlider/ProTaper Next showed better } \\
\text { preservation of canal anatomy (more } \\
\text { centering ability). }\end{array}$ \\
\hline $\begin{array}{l}\text { Türker and } \\
\text { Uzunoğlu, } 2015^{70}\end{array}$ & $\begin{array}{l}\text { Group 1: size } 10,15 \text {, and } 20 \text { K-files/ } \\
\text { ProTaper Next } \\
\text { Group 2: PathFile/ProTaper Next } \\
\text { Group 3: ProGlider/ProTaper Next } \\
\text { Group 4: ProTaper Next alone } \\
\text { Canal curvature: }\left(25^{\circ}-35^{\circ}\right) \text { (mesial canals of } \\
\quad \text { mandibular molars) }\end{array}$ & 2D digital radiography & $\begin{array}{l}\text { The ProTaper Next system maintained root } \\
\text { canal curvature well either with } \\
\text { pathfinding files or alone. Apical } \\
\text { transportation between groups was } \\
\text { insignificant. However, } 2 \text { files were } \\
\text { fractured in the ProTaper Next group. }\end{array}$ \\
\hline
\end{tabular}


TABLE 1 - Continued

\begin{tabular}{|c|c|c|c|}
\hline Author(s), year & Comparison & Methods for evaluation & Conclusion \\
\hline $\begin{array}{l}\text { Kirchhoff } \\
\text { et al, } 2015^{93}\end{array}$ & $\begin{array}{l}\text { Group 1: ProGlider } \\
\text { Group 2: PathFile } \\
\text { Canal curvature: (average of } 34^{\circ} \text { ) (mesial } \\
\quad \text { canals of mandibular molars) }\end{array}$ & Micro-CT imaging & $\begin{array}{l}\text { Similar apical transportation and volume } \\
\text { increase occurred in both groups. }\end{array}$ \\
\hline $\begin{array}{l}\text { de Carvalho } \\
\text { et al, } 2015^{67}\end{array}$ & $\begin{array}{l}\text { Group 1: size } 10 \text { and } 15 \mathrm{~K} \text {-files/Reciproc } \\
\text { Group 2: PathFile/Reciproc } \\
\text { Group 3: Reciproc } \\
\text { Group 4: no preparation } \\
\text { Canal curvature: }\left(20^{\circ}-30^{\circ}\right) \text { (mesial canals of } \\
\quad \text { mandibular molars) }\end{array}$ & CBCT imaging & $\begin{array}{l}\text { The different glide path techniques } \\
\text { promoted minimal apical transportation, } \\
\text { and the reciprocating single-file system } \\
\text { tested remained relatively centralized } \\
\text { within the root canal. }\end{array}$ \\
\hline $\begin{array}{l}\text { Hoppe } \\
\qquad \text { et al, } 2016^{71}\end{array}$ & $\begin{array}{l}\text { Group 1: ProTaper Universal } \\
\text { Group 2: WaveOne } \\
\text { Group 3: PathFile/SX ProTaperMaveOne } \\
\text { Canal curvature: }\left(20^{\circ}-40^{\circ}\right) \text { (mesial canals of } \\
\quad \text { mandibular molars) }\end{array}$ & CBCT imaging & $\begin{array}{l}\text { WaveOne was capable to provide similar } \\
\text { transportation and centering ability when } \\
\text { compared with ProTaper and combined } \\
\text { glide path/rotary/WaveOne in curved } \\
\text { canals. }\end{array}$ \\
\hline $\begin{array}{l}\text { Coelho } \\
\text { et al, } 2016^{72}\end{array}$ & $\begin{array}{l}\text { Group 1: size 10, 15, and } 20 \text { K-files/ } \\
\text { WaveOne } \\
\text { Group 2: WaveOne } \\
\text { Group 3: size 10, } 15 \text {, and } 20 \mathrm{~K} \text {-files/ } \\
\quad \text { Reciproc } \\
\text { Group 4: Reciproc } \\
\text { Canal curvature: }\left(25^{\circ}-39^{\circ} \text { ) (mesial canals of }\right. \\
\quad \text { mandibular molars) }\end{array}$ & 2D digital radiography & $\begin{array}{l}\text { Glide path had no influence on the } \\
\text { centering ability of these systems. }\end{array}$ \\
\hline $\begin{array}{l}\text { Paleker and } \\
\text { van der Vyver, } \\
2016^{59}\end{array}$ & $\begin{array}{l}\text { Group 1: size } 10,15 \text {, and } 20 \mathrm{~K} \text {-files } \\
\text { Group 2: ProGlider } \\
\text { Group 3: G-Files } \\
\text { Canal curvature: }\left(25^{\circ}-30^{\circ}\right) \text { (mesial canals of } \\
\quad \text { mandibular molars) }\end{array}$ & Micro-CT imaging & $\begin{array}{l}\text { The centering ability of the ProGlider file } \\
\text { was favorable at all } 3 \text { levels examined } \\
\text { within the instrumented root canals. } \\
\text { Overall, apical canal transportation } \\
\text { values were more favorable in the NiTi } \\
\text { rotary glide path file groups. The } \\
\text { ProGlider file and G-Files produced } \\
\text { statistically similar apical canal } \\
\text { transportation values in all directions. }\end{array}$ \\
\hline $\begin{array}{l}\text { Alovisi } \\
\quad \text { et al, } 2017^{94}\end{array}$ & $\begin{array}{l}\text { Group 1: size } 10,15 \text {, and } 20 \text { K-files/ } \\
\text { ProTaper Next } \\
\text { Group 2: ProGlider/ProTaper Next } \\
\text { Group 3: PathFiles/ProTaper Next } \\
\text { Canal curvature: }\left(25^{\circ}-40^{\circ} \text { ) (first }\right. \\
\quad \text { mesiobuccal canals of maxillary molars) }\end{array}$ & Micro-CT imaging & $\begin{array}{l}\text { The ProGlider appears suitable for glide } \\
\text { path management because it was } \\
\text { associated with less canal transportation } \\
\text { after shaping procedures with ProTaper } \\
\text { Next. }\end{array}$ \\
\hline $\begin{array}{l}\text { Camargo } \\
\text { et al, } 2019^{74}\end{array}$ & $\begin{array}{l}\text { Group 1: Reciproc }(25 / 0.08) \\
\text { Group 2: Prodesign } \mathrm{R}(25 / 0.06) \\
\text { Group 3: Mtwo }(25 / 0.06) \\
\text { Canal curvature: }\left(10^{\circ}-20^{\circ}\right) \text { (2 separate } \\
\text { canals in the mesiobuccal root of } \\
\quad \text { maxillary molars) }\end{array}$ & Micro-CT imaging & $\begin{array}{l}\text { All NiTi systems had similar canal } \\
\text { transportation, centering ability, and } \\
\text { increased apical volume after } \\
\text { preparation of second mesiobuccal } \\
\text { canals. However, the ProDesign R taper } \\
\text { had less volume of dentin removal and } \\
\text { absence of root canal perforation and } \\
\text { required a longer time to accomplish root } \\
\text { canal preparation. }\end{array}$ \\
\hline $\begin{array}{l}\text { Vorster } \\
\quad \text { et al, } 2018^{62}\end{array}$ & $\begin{array}{l}\text { Group 1: precurved \#10, 15, and } 20 \text { K-files/ } \\
\text { WaveOne Gold } \\
\text { Group 2: a \#10 K-file followed by PathFiles } \\
\text { \#1-3/WaveOne Gold } \\
\text { Group 3: a \#10 K-file followed by the } \\
\text { WaveOne Gold Glider/WaveOne Gold } \\
\text { Group 4: WaveOne Gold with no glide path } \\
\text { preparation } \\
\text { Canal curvature: }\left(25^{\circ}-35^{\circ}\right) \text { (mesiobuccal } \\
\text { canals of mandibular molars) }\end{array}$ & Micro-CT imaging & $\begin{array}{l}\text { The K-file groups showed the highest mean } \\
\text { transportation values during glide path } \\
\text { preparation. However, WaveOne Gold } \\
\text { performance regarding centering ability } \\
\text { and transportation was not influenced by } \\
\text { the different glide path/no glide path } \\
\text { preparation groups. }\end{array}$ \\
\hline $\begin{array}{l}\text { Zheng } \\
\text { et al, } 2018^{73}\end{array}$ & $\begin{array}{l}\text { Group 1: K-files/WaveOne } \\
\text { Group 2: PathFile/WaveOne } \\
\text { Group 3: ProGlider/WaveOne } \\
\text { Canal curvature: }\left(25^{\circ}-40^{\circ}\right)(2 \text { separate } \\
\quad \text { canals in mandibular first molars) }\end{array}$ & Micro-CT imaging & $\begin{array}{l}\text { Compared with the PathFiles and K-files, } \\
\text { the ProGlider file combined with the } \\
\text { WaveOne file showed reduced canal } \\
\text { transportation and working time. }\end{array}$ \\
\hline
\end{tabular}


TABLE 1 - Continued

\begin{tabular}{|c|c|c|c|}
\hline Author(s), year & Comparison & Methods for evaluation & Conclusion \\
\hline $\begin{array}{l}\text { van der Vyver } \\
\text { et al, } 2019^{60}\end{array}$ & $\begin{array}{l}\text { Group 1: precurved size 10, 15, and } 20 \\
\text { K-files } \\
\text { Group 2: size } 10 \mathrm{~K} \text {-file followed by One-G } \\
\quad \text { (MicroMega, Besançon, France) } \\
\text { Group 3: size } 10 \mathrm{~K} \text {-file followed by } \\
\text { ProGlider } \\
\text { Canal curvature: }\left(25^{\circ}-35^{\circ}\right) \text { (2 separate } \\
\text { mesiobuccal canals in maxillary first } \\
\text { molars) }\end{array}$ & Micro-CT imaging & $\begin{array}{l}\text { One-G and ProGlider were significantly } \\
\text { more centered at the apical, midroot, } \\
\text { and coronal levels than K-files. Apical } \\
\text { canal transportation ratio values after } \\
\text { glide path enlargement were significantly } \\
\text { higher for K-files than for One-G and } \\
\text { ProGlider. All groups resulted in similar } \\
\text { canal volume changes. }\end{array}$ \\
\hline $\begin{array}{l}\text { van der Vyver } \\
\text { et al, } 2019^{61}\end{array}$ & $\begin{array}{l}\text { Group 1: K-files } \\
\text { Group 2: One-G files } \\
\text { Group 3: ProGlider } \\
\text { Specimens of each glide path group were } \\
\text { further divided into } 3 \text { groups (ProTaper } \\
\text { Next, OneShape, and WaveOne Gold). } \\
\text { Canal curvature: ( } 25^{\circ}-35^{\circ} \text { ) (mesiobuccal } \\
\text { canals in maxillary first molars) }\end{array}$ & Micro-CT imaging & $\begin{array}{l}\text { WaveOne Gold combined with ProGlider } \\
\text { showed better root canal shaping ability } \\
\text { and removed less dentin from the canal } \\
\text { walls. The OneShape and ProTaper Next } \\
\text { instruments used in combination with } \\
\text { K-files significantly transported more } \\
\text { canals. ProTaper Next removed the most } \\
\text { dentine from the canal walls regardless of } \\
\text { the glide path preparation technique. }\end{array}$ \\
\hline
\end{tabular}

2D, 2-dimensional; CBCT, cone-beam computed tomographic; Micro-CT, micro-computed tomographic.

after SS file size 10 is used up to the WL, and they only perform a pre-enlargement of the root canal to facilitate the use of the shaping files. Apparently, an evidence-based guideline is needed to revise and define the basic concepts of negotiation, glide path, and preflaring procedures regarding the current advancements in NiTi instruments and kinematics. It seems more appropriate to categorize such clinical steps separately or combined based on the objectives of a given instrumentation procedure (ie, performing a glide path and preflaring separately or simultaneously).

\section{Experimental and Clinical Reports Glide Path Preparation}

\section{Centering Ability and Canal \\ Transportation. Numerous studies}

compared the centering ability, transportation, and ability to maintain the canal anatomy using different hand and rotary glide path files using various methodological procedures (ie, 2dimensional digital radiography, cone-beam computed tomographic imaging, and microcomputed tomographic imaging). Table 1 provides the details of the glide path studies included in this systematic review.

Several studies showed that the use of rotary glide path files preserved the original canal anatomy and caused less canal aberrations and transportations compared with the use of $\mathrm{K}$ files ${ }^{58-62}$. However, other studies found that glide path preparation failed to prevent the occurrence of apical transportation in curved canals $^{63,64}$. Notably, these 2 studies $^{63,64}$ used 2-dimensional digital radiography in comparison with micro-computed tomographic imaging in previous studies ${ }^{58,59}$. Studies reported comparable results between different rotary glide path files, as shown in Table 1.

The literature shows controversial results in regard to the effect of glide path files on the shaping properties of NiTi systems (Table 1). Several studies showed that hand or rotary glide path files enhanced centering ability and thus reduced the transportation of rotary and reciprocating shaping file systems $^{65-67}$. However, other studies did not support these findings ${ }^{68-72}$. A recent study showed that mechanical glide path preparation with ProGlider (Dentsply Sirona, York, PA) and PathFile (Dentsply Sirona) rotary systems followed by WaveOne (Dentsply Sirona) showed significantly less canal transportation than the use of K-files followed by the same system ${ }^{73}$. Another study compared the centering ability and transportation of Reciproc (R25; VDW, Munich, Germany) and Mtwo (25/ $.06, \mathrm{VDW}$ ) without a previous glide path preparation with Prodesign R (25/.06; Easy, Belo Horizonte, Brazil) with the previous use of PathFile in mesiobuccal canals of maxillary molars $^{74}$. Results showed that all systems had similar canal transportation, centering ability, and increase of canal volume after preparation. However, root perforations were observed in the Reciproc and Mtwo groups. One study showed that PathFiles resulted in more centric ability in mesial canals compared with V-Glide Path 2 files (SS White, Lakewood, NJ) ${ }^{75}$. Pasqualini et al ${ }^{76}$ showed neither systems (ProGlider/ProTaper Next [Dentsply Sirona] and ScoutRace/Bio-Race [FKG Dentaire, La Chaux-de-Fonds, Switzerland]) produced significant shaping errors in curved canals.

The use of different hand and rotary glide path file systems in tooth types with different canal curvatures analyzed using different diagnostic tools makes reliable comparisons between studies impossible. Therefore, a meta-analysis was performed to estimate the pooled standardized mean difference (SMD) using a random effects model. The SMD below 0 interpreted as the intervention (automated instrumentation) has less transportation compared with the control (hand instrumentation). Heterogeneity was found to be significantly present when the $l^{2}$ statistic was more than $50 \%$. Publication bias was not assessed because fewer studies were included. Figures 2 -5 show results of the meta-analysis. Results showed that the use of glide path preparation significantly reduces canal transportation $(P<$.05). However, automated glide path preparation produces significantly less canal transportation compared with hand glide path preparation, especially in the apical and middle thirds of the root $(P<.05)$.

\section{Apical Extrusion of Debris and}

Bacteria. Extruded debris from the apical foramen may contain microorganisms, dentin particles, and necrotic pulp tissue remnants, which may trigger inflammatory responses in the periapical area and subsequent postoperative pain and swelling ${ }^{77}$. Researchers found that creating a glide path preparation using the PathFile reduced the apically extruded debris when OneShape (MicroMega, Besançon, France) and WaveOne files were used in mandibular incisors $^{78}$. Topçuoğlu et al ${ }^{79}$ showed that a previous glide path with the PathFile before root canal shaping with Reciproc, OneShape, and WaveOne files in the mesial canals of mandibular molars tends to decrease the 


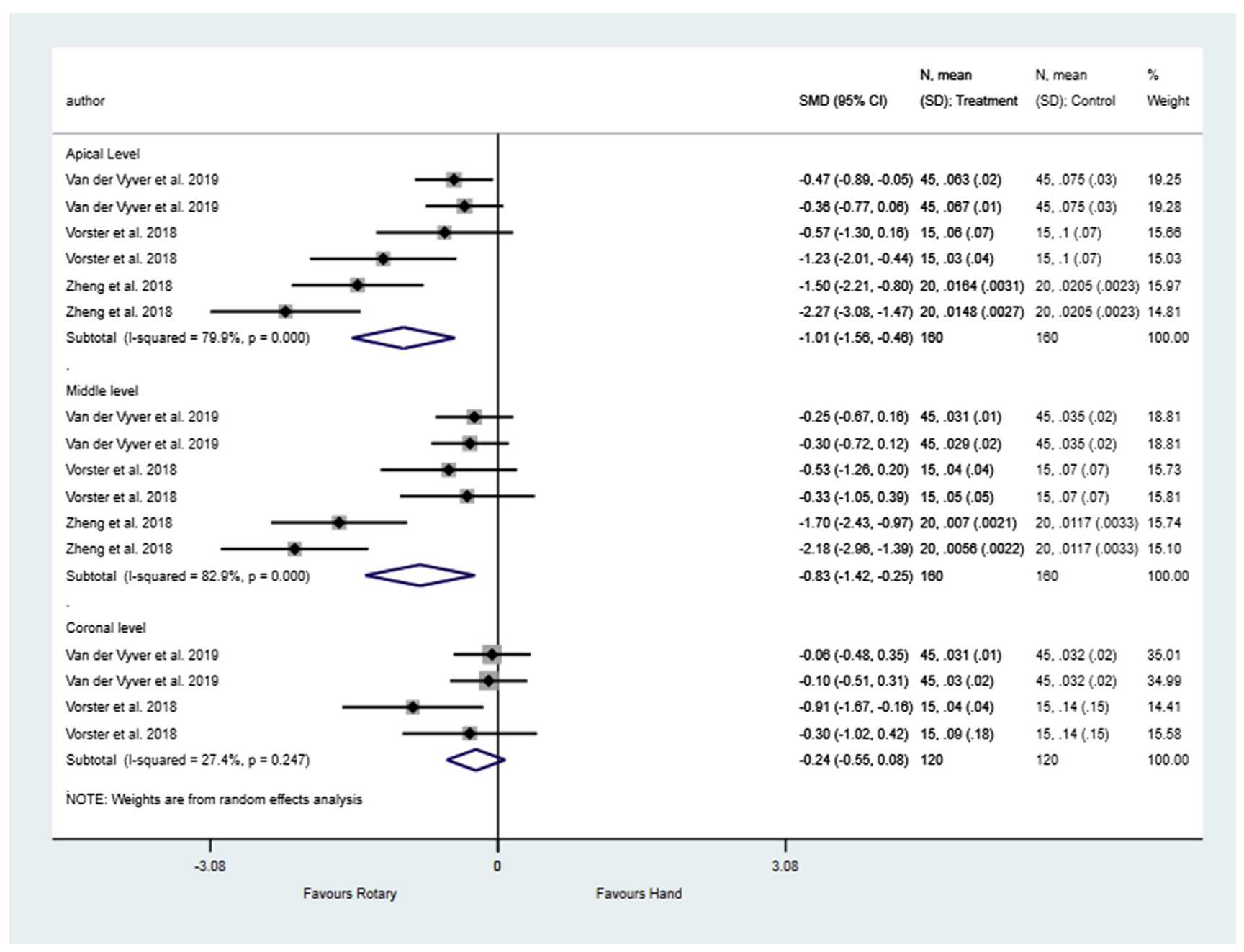

FIGURE 2 - Meta-analyses comparing hand with automated glide path preparation using 3 dimensional imaging. Automated instrumentation showed significantly less transportation compared with hand instrumentation in the apical (SMD $=-1.01 ; 95 \%$ confidence interval [Cl], -1.56 to -0.46 ) and middle thirds ( $\mathrm{SMD}=-0.83 ; 95 \% \mathrm{Cl},-1.42$ to -0.25 ), whereas no difference was observed in the coronal third $(\mathrm{SMD}=-0.24 ; 95 \% \mathrm{Cl},-0.55$ to 0.08 ) using micro-computed tomographic imaging (micro-CT).

amount of debris extrusion. Investigators found that creating a glide path using NiTi rotary files in mandibular incisors produced less amount of debris extrusion compared with using manual SS files ${ }^{77}$. Dagna et al ${ }^{80}$ compared the influence of using manual $\mathrm{K}$-files and 4 types of NiTi rotary glide path systems (PathFiles, G-Files (Micro-Mega, Besançon, France), ProGlider, and One G [MicroMega]) on the amount of bacteria extruded. Results showed that K-files were more susceptible to extrude bacteria compared with the 4 glide path systems, which is similar to the results obtained by 2 recent studies ${ }^{73,81}$. Using rotary glide path files before the Self-Adjusting File (ReDent Nova, Ra'annana, Israel) also showed favorable results ${ }^{82}$.

As per previous discussion, establishing the glide path using NiTi rotary instruments before root canal shaping significantly reduces the apical extrusion of debris and microorganisms compared with manual glide path preparations. However, it should be pointed out that postoperative pain, which usually results from periapical extrusion of debris, also depends on the patient's immune response as well as the virulence of the microorganisms extruded into the periapical tissues $^{83}$.

Root Dentin Defects. The literature shows controversies with the development of dentinal microcracks with various instrumentation procedures $^{84,85}$. One study revealed that no significant difference occurred in the incidence of dentinal defects in severely curved root canals when instrumented by a Reciproc single-file system with or without prior creation of a glide path ${ }^{86}$. Türker and Uzunoğlu ${ }^{87}$ showed that creating a glide path with the
ProGlider before shaping the canals with the ProTaper Next did not affect dentinal microcrack formation, which is in accordance with a recent study ${ }^{88}$. Similarly, a study by Topçuoğlu et al ${ }^{89}$ revealed that no difference in crack propagation was observed with or without the creation of a glide path with the PathFile. Kfir et $\mathrm{al}^{90}$ showed no significant differences regarding the presence of microcracks between the glide path created by 2 systems (Pre-SAF rotary [ReDent Nova] or ProFile). Based on findings from available studies and after considering their important limitations, glide path preparations do not impact dentinal microcrack formation in root canals prepared with rotary or reciprocating instruments. Notably, in a recent in situ cadaveric model, De-Deus et $\mathrm{al}^{91}$ proved the lack of preexisting dentinal microcracks in nonendodontically treated teeth. Furthermore, it was shown that dentinal microcracks 
Hand Vs Rotary - 2D (Apical level)

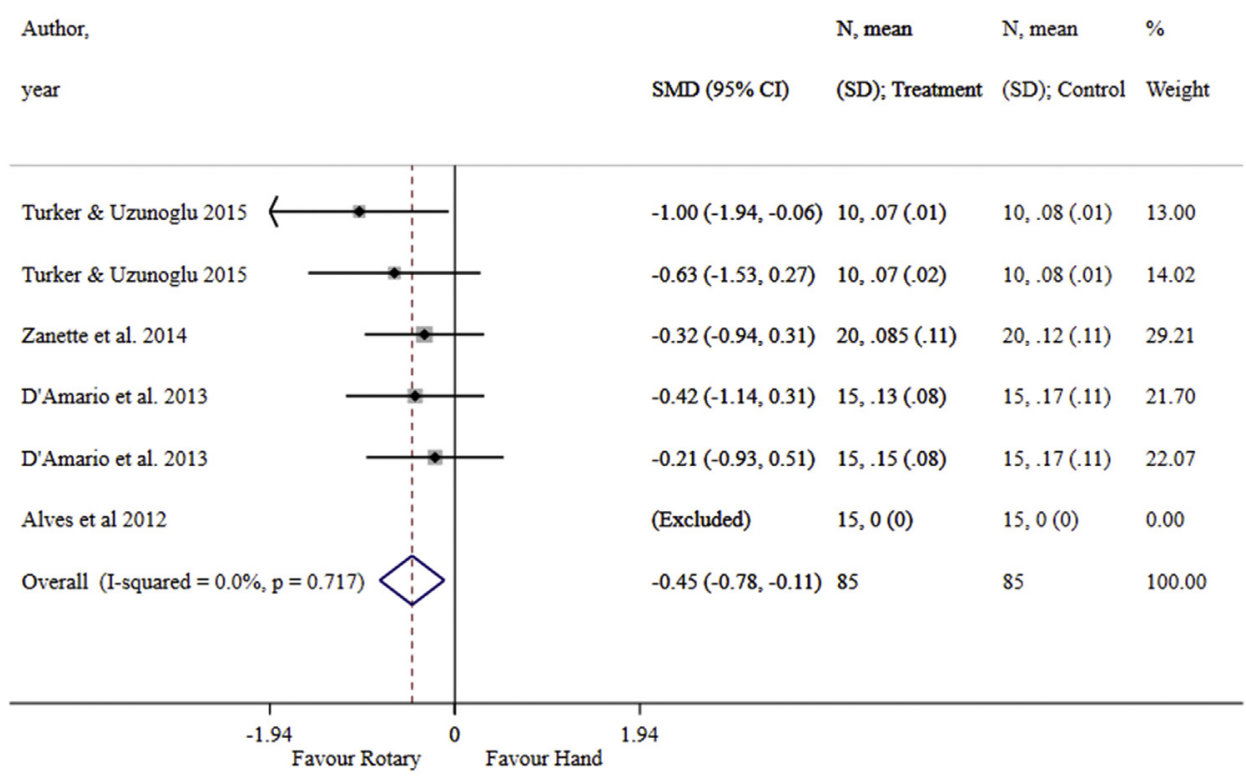

FIGURE 3 - Meta-analyses comparing hand with automated glide path preparation using 2 dimensional (2D) imaging. Automated glide path preparation showed significantly less transportation compared with hand glide path preparation in the apical third (SMD $=-0.45 ; 95 \% \mathrm{Cl},-0.78$ to -0.11 ) when assessed using $2 \mathrm{D}$ diagnostic technique.

observed in stored extracted teeth subjected to root canal procedures are, in fact, a result of the extraction process and/or the postextraction storage conditions.

\section{ST and GPT. Reducing the ST enables} clinicians to spend extra time to renew sodium hypochlorite and to use activation techniques to enhance cleaning and disinfection ${ }^{8}$. Several works have investigated the impact of creating a prior glide path on the ST. Uroz-Torres et al ${ }^{68}$ found no significant difference in the ST when Mtwo instruments were used with or without a manual glide path (\#08-15, K-files). Another study showed that the application of glide path files decreased the ST of OneShape and WaveOne files ${ }^{78}$. Coelho et al ${ }^{72}$ reported that a manual glide path using K-files increased the total ST in curved canals with WaveOne and Reciproc instruments. One study found that ST using WaveOne was reduced compared with the use of ProTaper Universal (Dentsply Sirona) and a hybrid technique (PathFile and SX ProTaper Universal followed by WaveOne $)^{71}$.

Other investigations have evaluated GPT using different systems. Two studies showed that the glide path was created faster using rotary (ProGlider) and reciprocating (WaveOne Gold Glider [Dentsply Sirona]) instruments compared with the use of SS manual K-files ${ }^{92,93}$. Paleker and van der Vyver ${ }^{92}$ found no significant difference in GPT between 2 rotary systems (ProGlider and GFiles), whereas 2 studies $^{93,94}$ found that ProGlider required less GPT than the PathFile. Vorster et $\mathrm{al}^{95}$ showed that reciprocating glide path instruments (WaveOne Gold Glider) provided faster GPT compared with the rotary PathFile system (the time taken to change the instruments was not considered in this study). Overall, using a single-file glide path system resulted in less GPT compared with multiple glide path file systems. Evidently, the use of automated instruments, rotary or reciprocating, for glide path procedures decreased GPT compared with the use of manual K-files.

\section{Instrument Fracture and Surface}

Defects. Instrument separation occurs because of cracks initiating from areas with high stress or surface irregularities ${ }^{96}$. One study found that using SS hand files for creating a manual glide path in curved canals decreased the occurrence of NiTi rotary file separation $^{32}$. However, this finding was contradicted by a number of studies that showed that glide path preparation had no impact on the surface topography or fracture rate of reciprocating and rotary files ${ }^{97-99}$ or the cyclic fatigue resistance of Reciproc and Reciproc Blue $(V D W)^{100}$. One study showed that SS K-files are more prone to surface defects compared with PathFiles ${ }^{96}$. A recent study showed that PathFile rotary files and
ProGlider files had no effect on the peak torque and force of ProTaper Gold rotary files (Dentsply Sirona) when used in narrow mesial canals in mandibular molars ${ }^{101}$. Notably, glide path files may develop various peak torques and forces during glide path preparation because of different flute diameters along their length $^{102}$.

Clinical Trials. Postoperative pain is a common problem faced by dental practitioners and affects the quality of life of patients. The incidence of pain after endodontic treatment ranges from 3\%$58 \%{ }^{103}$. Pasqualini et $\mathrm{al}^{104}$ showed that a glide path using rotary files reduced postoperative pain incidence and analgesic prescription compared with a manual glide path using SS K-files. This finding may be attributed to several factors, such as less apical extrusion of debris, better dentinal debris removal, and a lower number of instruments used compared with a manual glide path. A recent randomized clinical trial compared the intensity and incidence of postoperative pain after glide path preparation with manual (SS K-files), continuous rotary (ProGlider), and reciprocating (R-Pilot, VDW) glide path instruments in teeth scheduled for single-visit root canal treatment using the ProTaper Next rotary system followed by the cold lateral compaction technique ${ }^{105}$. Results showed that preparation of a glide path with 


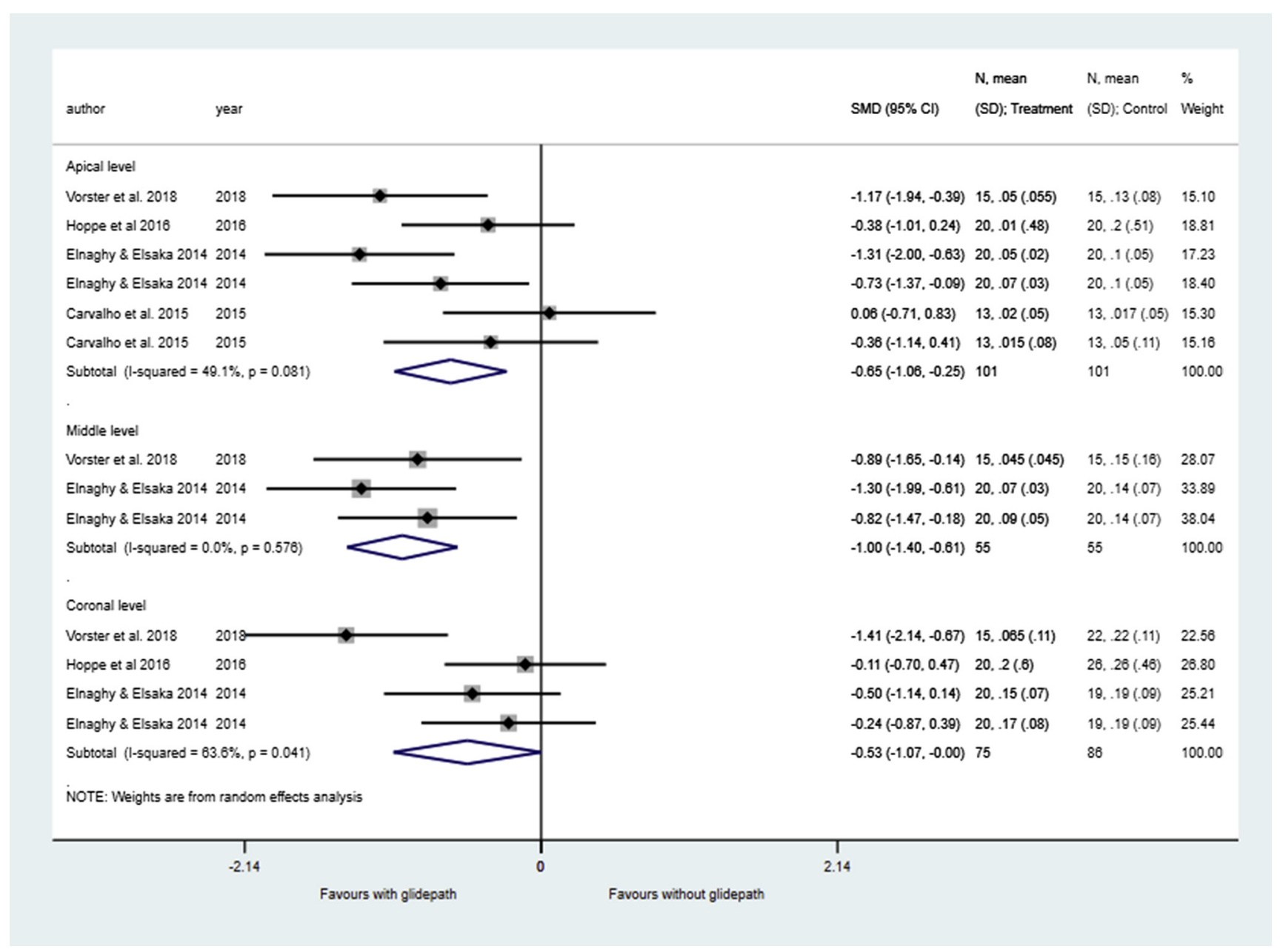

FIGURE 4 - Meta-analyses comparing Ni Ti instrumentation with and without glide path preparation. Glide path preparation showed significantly less transportation compared with instrumentation without glide path preparation $(\mathrm{SMD}=-0.65 ; 95 \% \mathrm{Cl},-1.06$ to -0.25$)$, middle third (SMD $=-1.00 ; 95 \% \mathrm{Cl},-1.40$ to -0.61 ), and coronal third level (SMD $=$ $-0.53 ; 95 \% \mathrm{Cl},-1.07$ to -0.00$)$ using the 3-dimensional diagnostic method, but the difference is not statistically significant.

rotating or reciprocating instruments was associated with less postoperative pain levels and incidence compared with manual glide path preparation with no significant difference between rotating and reciprocating instruments.

Negotiability of Root Canals by Single-File Systems. Several studies have examined the ability of file systems to negotiate root canals and reach the $\mathrm{WL}^{7,106,107}$. De-Deus et al ${ }^{106}$ showed that Reciproc R25 (VDW) can reach the WL in mandibular molars without prior glide path creation. Notably, Reciproc instrumentation reached the full WL in $93.4 \%$ of root canals without glide path preparation (90.7\% and $96.4 \%$ of curved and straight canals, respectively). A similar ex vivo study showed that the vast majority of curved canals can be prepared using Reciproc and Reciproc Blue R25 instruments without glide path preparation ${ }^{107}$. Furthermore, a manual or automated glide path preparation was not associated with an improvement in the ability of the tested systems to reach the full WL. Another clinical study examined the ability of Reciproc R25 to negotiate and reach the WL in second mesiobuccal canals in maxillary molars compared with conventional hand file negotiation ${ }^{7}$. Results showed that R25 was notably more effective than hand files and reached the WL in approximately $86 \%$ of cases compared with $57 \%$ for hand files. This finding might be attributed to the kinematics and cross section of the instrument ${ }^{108}$ and the flexibility of the R25 M-Wire alloy and its high cutting efficiency ${ }^{109-111}$. Another study showed the ability of Reciproc to reach the $\mathrm{WL}$ in primary and retreatment cases without glide path preparation ${ }^{112}$, reporting that $95.6 \%$ of root canals could be prepared to the full WL and that a creation of the glide path may have no impact on the Reciproc files in reaching the $\mathrm{WL}$. In the previously mentioned studies, after reaching approximately two thirds of the canal with a Reciproc R25 file without any previous hand filing, the authors followed the manufacturer's recommendation by introducing a size 10 hand file passively in the canal with a watch-winding motion with the purpose of determining the WL. De-Deus et $\mathrm{al}^{106}$ showed that further use of the R25 instrument was also able to reach the WL in $67.3 \%$ of the root canals in which the size 10 hand file was unable to gently advance to the WL after coronal and middle third preparation. This finding also supported the scouting ability of this instrument even in nonnegotiable canals.

\section{Preflaring}

Apical File Size Determination. Adequate apical preparation of the root canals plays a key role on the outcome of root canal treatment ${ }^{113}$. Apical enlargement is implemented after evaluation of the apical 


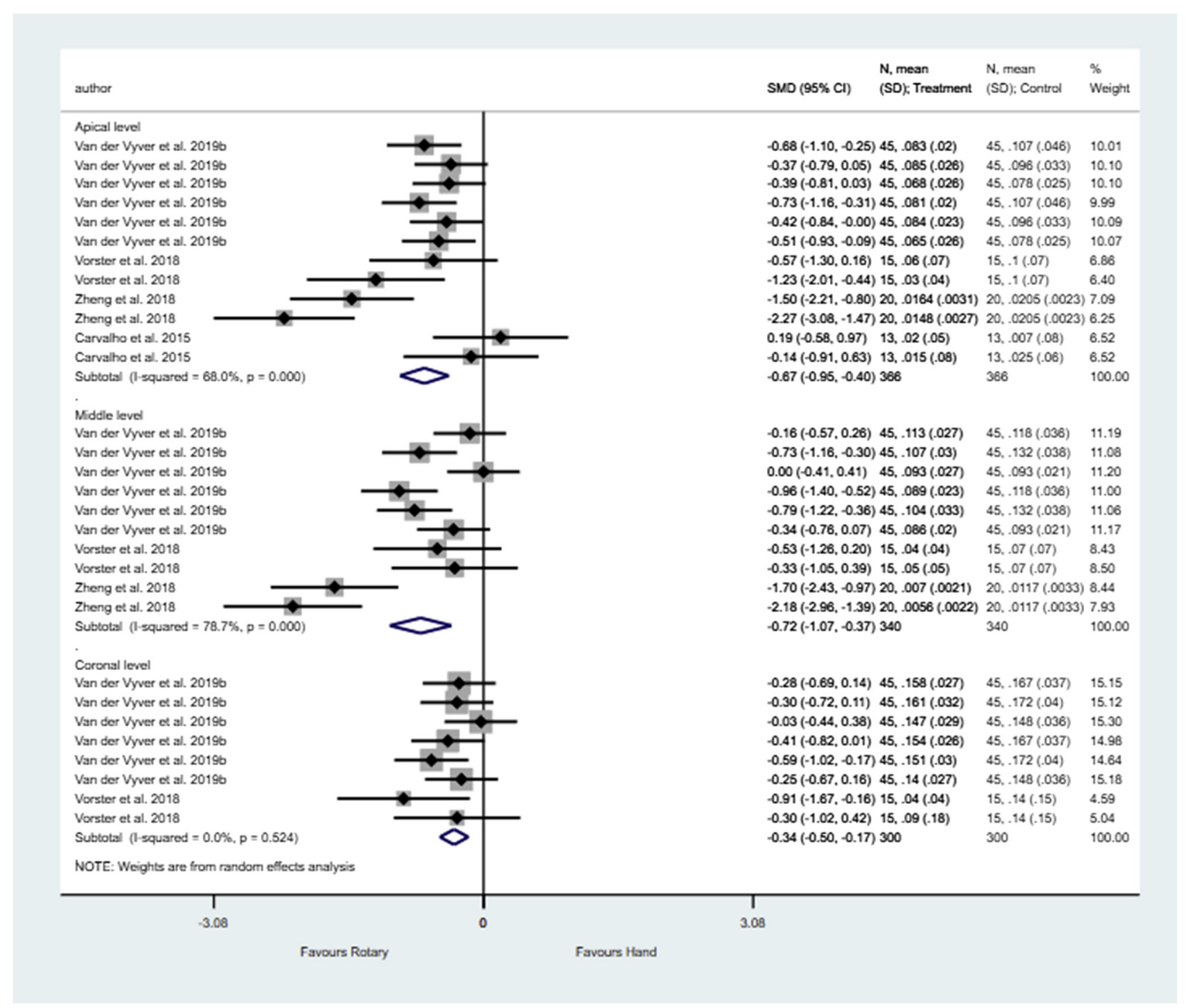

FIGURE 5 - Meta-analyses comparing glide path preparation followed by the same system. Automated instrumentation showed significantly less transportation compared with hand instrumentation in the apical ( $\mathrm{SMD}=-0.67 ; 95 \% \mathrm{Cl},-0.95$ to -0.40 ), middle $(\mathrm{SMD}=-0.72 ; 95 \% \mathrm{Cl},-1.07$ to -0.37 ), and coronal thirds (SMD $=-0.34 ; 95 \% \mathrm{Cl},-0.50$ to $-0.17)$.

constriction diameter. The initial apical file (first binding file) size is determined by tactile sense of the apical constriction through the sequential insertion of instruments (from small such as K-file size 10 to larger) to the WL until binding occurs $^{114}$. This procedure can be properly performed only after shaping the coronal and middle third using the crown-down technique. Otherwise, the coronal canal dentin can prevent the instrument from reaching the full WL, which might result in a ledge $^{115}$. The, apical diameter

determination may also become inaccurate because of a false tactile sense of the apical constriction ${ }^{116}$.

Stabholz et al $^{117}$ showed that coronal preflaring enhances the determination of the apical constriction by tactile sensation. Investigators showed that coronal and middle preflaring of the canals influences the apical sizing by K-files and Lightspeed instruments (Lightspeed Technology Inc, San Antonio, $T X)^{35}$. Two studies showed that canals preflared coronally with LA Axxess burs (SybronEndo, Glendora, CA) resulted in a more accurate binding of the files to the anatomic diameter compared with the use of GG drills, K3 Orifice Openers (Kerr Dental, Orange, CA), ProTaper instruments, and no flaring in maxillary molars ${ }^{118}$ and premolars ${ }^{119}$. Similar results have been reported in other studies $^{116,120-122}$. Tennert et al ${ }^{115}$ found that mesiobuccal canals in maxillary molars preflared coronally with $\mathrm{RaCe}$ instruments (FKG Dentaire, La-Cheaux-de-Fonds,
Switzerland) showed minimum discrepancy between the apical root canal diameter and the initial apical file diameter followed by ProTaper and FlexMaster (VDW). In mandibular molars, preflaring with $L A$ Axxess burs produced minimal discrepancies followed by EndoFlare instruments (MicroMega), GG drills, and ProTaper files. No statistically significant differences were found among various rotary instruments in another study ${ }^{123}$. Another investigation showed that coronal preflaring with $\mathrm{RaCe}$ instruments led to an accurate determination of the initial apical file followed by ProTaper, Galaxy files (Plastic endo, Lincolnshire, IL), and GG drills ${ }^{124}$. Overall, researchers showed that coronal preflaring related to the crown-down technique increases the accuracy of the determination of 

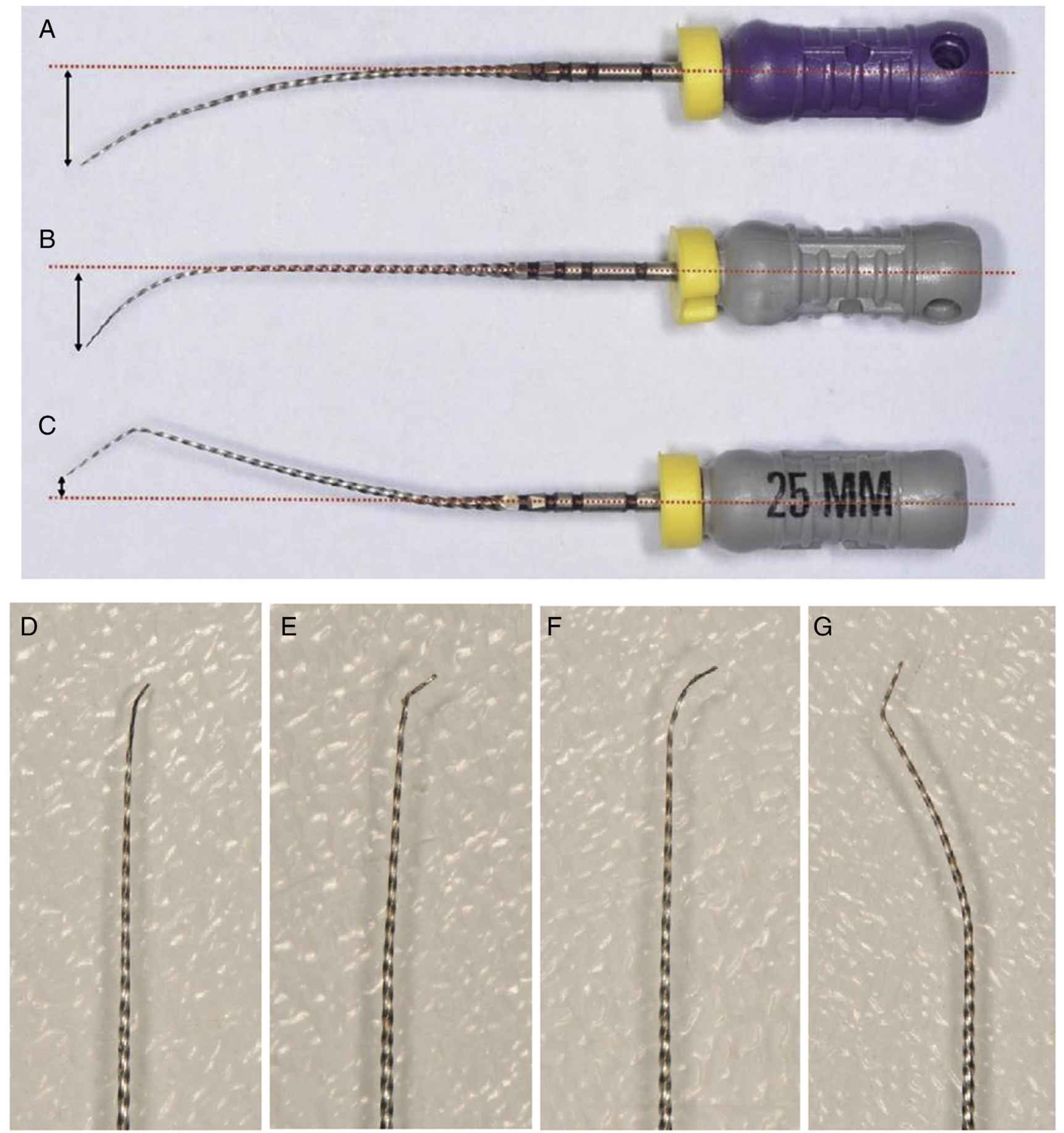

FIGURE 6 - Photographic images showing manual precurvature of SS hand files. $(A-C)$ The image shows the distance between the file tip and the long axis of the file after different precurvatures of the tip with different types of precurvature. It is evident how with type $C$ it is possible to have the coincidence of the tip with the axis of the file (in $S$-shaped canals). ( $D$ and $E$ ) Apical abrupt precurvature with different angles (elbow-like curvatures), $(F)$ regular apical precurvature (banana-like curvatures), and $(G)$ double precurvature.

the first file that binds to the $\mathrm{WL}^{125}$ and promotes accurate apical size determination $^{126}$.

WL Determination. Several studies examined the effect of coronal preflaring on the accuracy of WL determination. Two studies showed that coronal preflaring increases the tactile detection of the apical constriction $^{117,127}$. Iqbal et al ${ }^{128}$ reported more accurate $\mathrm{WL}$ determination in coronally flared curved canals compared with unflared canals. Three studies observed that there was a change in the WL after coronal preflaring ${ }^{36,129,130}$. An in vivo study showed that in $72.5 \%$ of coronally flared canals and in $27.5 \%$ of unflared canals, the file was located within the last apical millimeter ${ }^{131}$. Three studies proved that coronal preflaring increased the accuracy of WL determination with electronic apex locators ${ }^{132-134}$. On the contrary, only 1 study showed that coronal preflaring did not enhance the accuracy of 

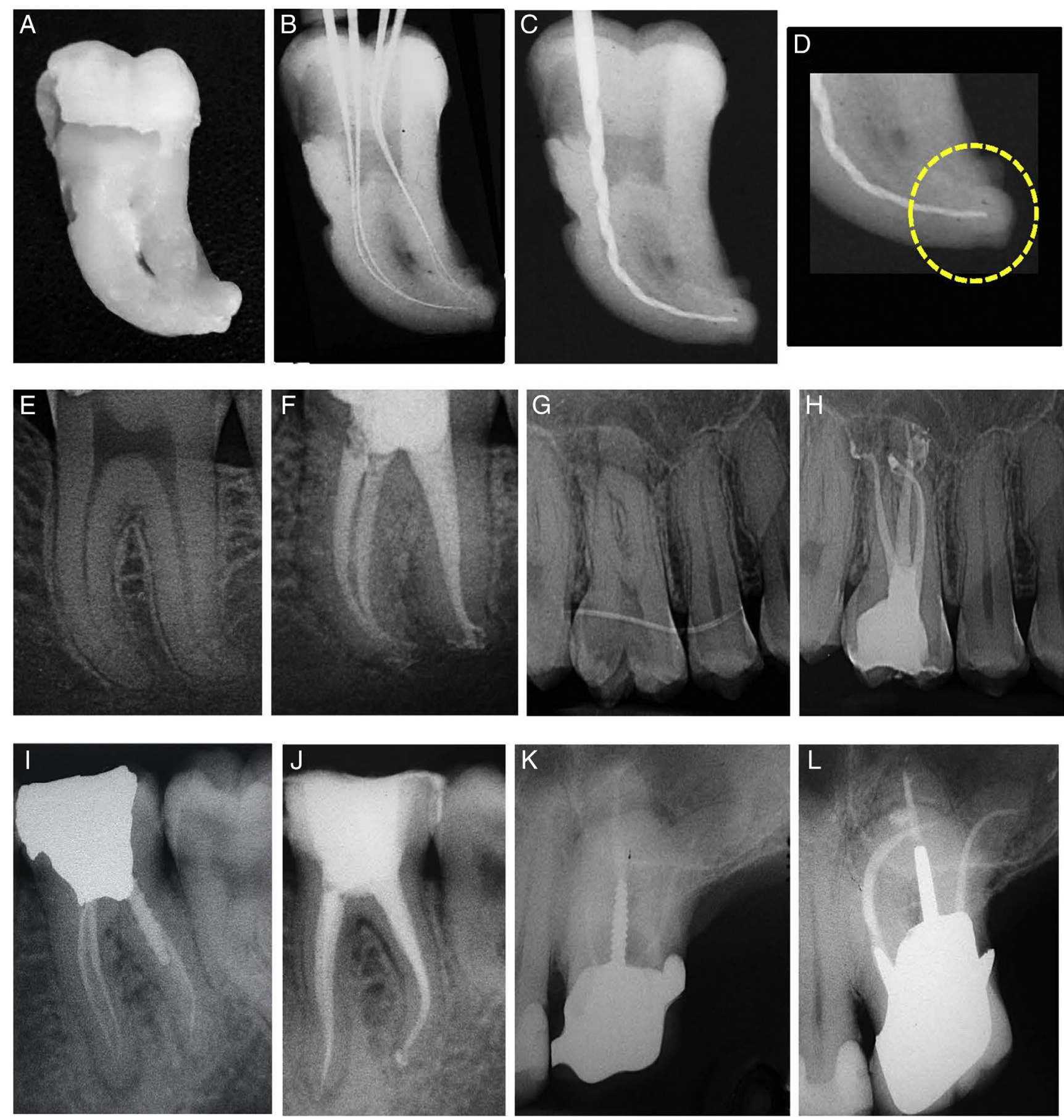

FIGURE 7 - $(A-D)$ Root canal instrumentation of a severely curved root canal in the mesial root of an extracted mandibular molar. D-Finders sizes 8, 10, 12, and 15 followed by SILK files (Complex Kit - file size 25/0.04) (Mani, Japan) were used for root canal shaping. The file remained centered inside the canal. ( $E$ and $F$ )Root canal treatment of a mandibular first molar in which the mesial and distal canals showed moderate curvatures. Negotiation and glide path preparation were performed using SS files size 08 and 10 , and NiTi rotary files were used for root canal shaping. ( $G$ and $H$ ) Root canal treatment of a maxillary first molar with severely curved, narrow mesiobuccal and distobuccal root canals. Negotiation and glide path preparation were performed using SS files size 08 and 10. Automated NiTi files were used to perform glide path pre-enlargement before root canal shaping with heat-treated NiTi files. $($ / and $J)$ Root canal retreatment of a mandibular molar with moderately curved distal root canal. After removal of root canal filling materials, negotiation and glide path preparation were performed using SS hand files sizes 8-10, followed by automated NiTi files ( $K$ and $L$ ) Root canal retreatment of a severely curved mesio-buccal and disto-buccal roots in a maxillary first molar. After removal of root canal filling materials, SS hand files sizes 8-10 followed by automated NiTi files were used.

electronic measurements in human incisor and canine teeth, which usually do not have narrow coronal orifices and/or curved canals $^{135}$. Overall, preflaring the coronal third of root canals greatly improves the tactile sense to the apical constriction and increases the accuracy of WL determination.
Root Dentin Defects. Dentinal microcracks created by root canal shaping have been strongly overestimated because of methodology issues in numerous studies, 
especially the use of the sectioning technique ${ }^{136,137}$. Although the clinical relevance of these studies remains debatable. root canal shaping results in stress concentration $^{138,139}$, which may become transmitted toward the canal walls and result in crack propagation, thus leading to vertical root fractures $^{140}$. Arslan et al ${ }^{139}$ showed that GG drills led to increased incidence of dentinal microcracks compared with ProTaper Universal (SX), EndoFlare, Revo-S (MicroMega), and HyFlex (Coltene, Langenau, Germany), which were similar to the control group (left unprepared). Borges et $\mathrm{al}^{141}$ compared the instrumentation of several systems (Reciproc, WaveOne, ProTaper Universal, ProTaper Next, ProFiles, and K-files driven by an oscillatory system) with and without coronal preflaring. Results showed that coronal preflaring reduced the incidence of root dentin defects under stereomicroscopic observation. Based on the above, the benefit of coronal preflaring to reduce root dentin defects triggered by root canal preparation remains unclear.

Root Dentin Thickness. Excessive removal of dentin after coronal flaring may result in perforation and treatment failure $e^{47,142}$. Investigators showed that GG removed substantially more dentin compared with M-series canal openers (Caulk Dentsply, Milford, DE $)^{47}$. Notably, the use of GG drills in mandibular molars may result in perforations; the application of anticurvature pressure did not reduce the risk ${ }^{143}$. This finding could be attributed to different file designs (cross section, size, and taper) among the instruments used in comparison with GG burs. Homayoon et al ${ }^{144}$ compared GG, K3, ProTaper, FlexMaster, and RaCe instruments in removing dentin during coronal flaring at 1.5 and $3 \mathrm{~mm}$ distances from the furcation zone toward the apex using cone-beam computed tomographic imaging. Results showed no differences among the instruments at $1.5 \mathrm{~mm}$, whereas a notable difference was observed at $3 \mathrm{~mm}$ between the FlexMaster and GG instruments. Akhlaghi et $\mathrm{al}^{45}$ showed no significant difference in minimum residual root thickness between ProTaper, RaCe, and GG instruments, which is in accordance to the results of a previous study ${ }^{142}$.

\section{Separation of Endodontic}

Files. Separation of endodontic files is a common problem faced by practitioners; it is caused by cyclic or flexural fatigue and the torsional stress phenomenon ${ }^{145}$. Cyclic fatigue occurs when the instrument rotates in the curved canal that is undertaking repeated compression-tension cycles ${ }^{145}$. Torsional fatigue occurs when the tip of the instrument binds in the root canal during rotation, thereby leading to fracture ${ }^{145}$. A prospective clinical study showed that preflaring with manual files and GG drills followed by instrumentation with the Mtwo system resulted in a lower incidence of file separation ${ }^{43}$. Likewise, 2 in vitro studies showed that preflaring decreased the risk of file separation ${ }^{34,146}$. Overall, preflaring (including coronal preflaring) decreases the chances for rotary files separation by reducing the surface area for contact of the instrument with the dentin walls. Preflaring may also have an important role in single-file systems because it may facilitate the penetration of the shaping file and prevent coronal binding ${ }^{146}$.

Transportation and Canal Cleanliness. A study investigated the effect of coronal preflaring on apical canal transportation when balanced force instrumentation was used in curved canals $^{147}$. Results showed that despite coronal preflaring facilitated the instrumentation procedure, significant differences were not found. Heard and Walton ${ }^{148}$ showed no difference in terms of canal cleanliness when instrumentation was performed with the step back technique with or without coronal preflaring. Sinan et al ${ }^{149}$ showed that coronal preflaring instruments (Quantec Flare LX [Tycom Dental, Irvine, CA] or EndoFlare) remained centered with no significant differences. Another study found that canals prepared with Reciproc and WaveOne with or without coronal preflaring showed no significant differences for apical canal transportation ${ }^{150}$. Investigators compared canals prepared with a ProTaper Universal system, WaveOne, and a hybrid technique on the association of reciprocating preparation to rotary glide path and cervical pre-enlargement ${ }^{71}$. No significant differences were found on the canal transportation and centering ability. According to this discussion, coronal preflaring does not have an impact on apical transportation.

Apical Extrusion of Debris. The amount of extrusion may vary according to instrument design, instrumentation technique, number of files used, apical size of the preparation, and kinematics ${ }^{151}$. Topçuoğlu et $\mathrm{al}^{152}$ showed that coronal preflaring followed by instrumentation with Reciproc and WaveOne systems resulted in less extrusion of debris compared with using them without preflaring, whereas root canal shaping with OneShape after preflaring did not affect the amount of debris extrusion. Borges et $\mathrm{al}^{153}$ showed that coronal preflaring reduced the amount of debris extrusion when Reciproc, WaveOne, ProTaper Universal, ProTaper Next, ProFile, and K-files were used for instrumentation. The coronal canal space created by the preflaring procedure acted as a reservoir for the irrigant to coronally flush the debris resulting from root canal preparation, which minimized their extrusion beyond the apical foramen.

\section{Clinical Considerations Negotiable Root Canals}

Negotiable root canals are those in which the instruments can easily reach the WL. Such canals are typically wide and straight or with minimal curvatures. If the clinician has to exert clockwise/counterclockwise watch-winding movements using a size $10 \mathrm{~K}$-file to reach the $\mathrm{WL}$, then the canal is narrow but can be negotiated sufficiently up to the apical foramen. When clinicians deal with canals with the previously mentioned characteristics, the shaping files can be used immediately after canal negotiation (and glide path files if needed $)^{8,49}$. Automated file systems that limit the use of hand SS files can be advantageous to reduce the risk of iatrogenic errors related to SS file stiffness.

\section{Root Canals with Difficult Negotiation}

If it is difficult to initially negotiate the canal using a size $10 \mathrm{~K}$-file, then it can be defined as a challenging root canal. The following criteria describe the characteristics of such canals.

\section{Canals with Difficult Coronal}

Negotiation. Several cases show a resistance to negotiation in the coronal third of the root. A second mesiobuccal canal in the mesiobuccal root of maxillary molars is a typical example of such cases ${ }^{25,154,155}$. The second mesiobuccal canal orifice is typically covered by a dentin shelf that, if not removed, it will guide the path of the hand instruments used for initial negotiation in a horizontal mesial direction. The problem encountered for scouting such canals is the abrupt curvature of the first 2-3 $\mathrm{mm}$ of the canal in a distal direction ${ }^{156}$. For this reason, when clinicians perform manual scouting with rigid hand SS files, the tip is guided by the shelf of dentin that covers the canal orifice toward the mesial wall of the canal. At this point, a small ledge or irregularity may be created, thus impairing further negotiability of such canals.

The early removal of this dentin shelf is the key for obtaining straight-line access to the canal. The removal of this dentin shelf with high- or low-speed burs or with ultrasonic tips may be difficult and time-consuming and may 
result in unnecessary cutting of the sound cervical dentin. For this step, the clinician may take advantage of the initial use of mechanical $\mathrm{NiTi}$ files instead of manual SS files. An NiTi instrument, given its flexibility and cutting ability, can proceed gently over the first coronal curvature, selectively straighten this portion of the root canal, and create an ideal pathway for the same instrument to proceed apically. A reciprocating NiTi single file with high flexibility and cutting ability may be beneficial ${ }^{7,8,106}$ because reciprocating instruments may not require a glide path or early coronal enlargement because the risk of torsional fracture is minimized ${ }^{8,20}$. This movement also avoids locking of the tip that cannot rotate for a greater angle with respect to the limit of fracture by torsion.

\section{Narrow Canals with Regular}

Curvatures. In narrow canals with regular curvatures in which an size $10 \mathrm{~K}$-file presents difficulties in negotiation and does not advance with gentle clockwise/counterclockwise watch-winding movements, the clinician should pay extra attention to avoid creating potential mishaps. A size 10 SS K-file, even if small, is relatively rigid and if forced into the canal may easily create a ledge or break inside the canal. For this reason, a size $08 \mathrm{~K}$-file can be used following the same procedures described previously. The file will then advance to the apical foramen, and a limited preenlargement can be achieved. The clinician will then be able to reach the WL with the size 10 $\mathrm{K}$-file. If the clinician finds difficulty even with the size $08 \mathrm{~K}$-file, the use of a size $06 \mathrm{~K}$-file may be necessary, and the same procedures undertaken previously can be repeated up to K-file size 10.

\section{Canals with Abrupt Apical Canal}

Curvatures. When a root canal shows an abrupt or severe apical canal curvature, the clinician should never force SS hand instruments because even a small alteration of the original canal anatomy may render proper scouting difficult or even impossible. Precurving the tip of the file is a strategy that can be used for such canals (Fig. 6A-C). The clinician should precurve $1-2 \mathrm{~mm}$ of the file tip with a sharp bend $\left(60^{\circ}-90^{\circ}\right)$ (Fig. $\left.6 D-G\right)$. The main challenge in such cases is to bring this instrument to the apical third without losing this prebending on its way inside the root canal. To achieve this, a crown-down preparation technique is recommended slightly coronal to the apical point in which manual scouting is successful. This procedure aims to remove dentin that narrows the canal lumen and provide sufficient space for the prebent file to reach the apical third, thereby maintaining the prebending. When performing this technique, reducing the scouting length to $1 \mathrm{~mm}$ is recommended to prevent the risk of a ledge. Furthermore, frequent and thorough irrigation with sodium hypochlorite and chelating agents is strongly recommended to lubricate the scouting file and to avoid debris accumulation into the apical area, thus creating additional challenges to subsequent scouting attempts. The coronal space created in the preflaring phase will also enable the clinician to direct the bent tip of the file with different inclinations to search for the direction of the apical curvature.

In general, it is recommended to begin these procedures with a size $08 \mathrm{~K}$-file. If unsuccessful during the initial scouting attempts, then the clinician should continue using a size $06 \mathrm{~K}$-file. Using quarter-turn movements, the clinician will be able to orient the precurved file in different directions until identifying the position of the apical curve and, finally, negotiate the canal. At this point, the clinician should not withdraw the instrument out of the canal because it may be difficult to reach the apical foramen again. The operator has to maintain the instrument at the $\mathrm{WL}$ and perform watch-winding movements with minimal apicocoronal vertical movements. These movements aim to slightly achieve patency to the abrupt apical canal curvature. Noting the direction of the apical curvature using the landmark on the silicone stopper is also helpful.

The clinician may take advantage of the initial use of an NiTi file for root canal preparation instead of manual SS files. A small reciprocating instrument with high flexibility and cutting ability may be beneficial ${ }^{157,158}$ given the fact that the risk of torsional fracture is minimized ${ }^{8,20}$. The risk of fracture by fatigue is also minimized by the small size, the design of the file, and the movement ${ }^{157,158}$.

Figure $7 A-L$ shows the root canal management of mandibular and maxillary molar teeth with various canal curvatures.

\section{Nonnegotiable Apical Canal}

\section{Anatomy. Despite technological}

advancements and continuous improvements in alloys and file movements and clinical skills, a few extremely challenging canals occur in which the scouting of the apical 1-2 mm may be impossible because of irregularities in the apical third and complex anatomy. Such cases may require a slightly different approach by focusing more on the chemical component of the root canal treatment procedures to remove the organic and inorganic contents from the untreated part of the root canal ${ }^{159}$.

\section{A Need for Consistent Reporting for Glide Path and Preflaring Procedures}

To prevent confusion, this systematic review categorized studies based on their objectives and maintained the original consideration of glide path files. It is obvious that most of the previous studies investigating the effects of glide path procedures were designed according to the manufacturers' recommendations. Therefore, less attention was given to the original basic concepts of glide path preparation and whether these systems fulfilled these concepts or not. The terminology used for these files can be confusing and remains debatable. This semantic controversy is not only because of marketing perspectives but also a result of various glide path systems and shaping protocols used by clinicians. Indeed, as mentioned previously, most of the rotating/ reciprocating instruments commonly marketed as "glide path files" or "pathfinding systems" are in reality "preflaring files" because most of the time, a prior manual glide path would be established before their use. On the contrary, as it was mentioned in this systematic review, some clinicians and manufacturers consider the canal negotiation and glide path procedures as optional before root canal shaping.

The authors believe that automated NiTi file systems that require a preliminary glide path with hand files up to size 10 or more have to be considered and named as "preflaring files" because they are only used for glide path enlargement. Current limitations of instruments present in the market underline the need for the introduction of new systems that may help the clinician to solve the most difficult cases described earlier, especially when a manual glide path is difficult or even impossible to establish.

As discussed earlier, it seems inappropriate to compare the SS K-files used for glide path preparation with those automated files with larger sizes/tapers because the latter may not fulfill the basic concept of glide path preparation. It is also strongly recommended that manufacturers consider the appropriate commercial name of a given file consistent with its clinical use (such as the inclusion of the word "glide, etc" in the file name if the file is used for glide path preparation). This would prevent 
confusion and misinterpretation of the purposes of such files.

\section{CONCLUSIONS}

The following conclusions can be drawn:

- An evidence-based guideline is needed to define and correlate the basic concepts and current applications of each step regarding contemporary advancements in root canal instruments.

- The use of glide path preparation significantly reduces canal transportation. Automated glide path preparation produces significantly less canal transportation and more preservation of the original canal anatomy compared with hand glide path preparation.

- Glide path preparation reduces the risk of debris extrusion.

- The glide path does not influence dentinal microcrack incidence.
- Automated glide path preparation reduces ST and GPT compared with the use of manual files.

- Glide path preparation does not reduce the incidence of instrument surface defects or separation.

- The creation of the glide path may have no impact on Reciproc in reaching the full WL.

- Coronal preflaring reduces the discrepancy between the initial apical file and the actual diameters of the minor apical foramen, enhances the tactile sensation of the apical constriction, and increases the accuracy of WL determination.

- Coronal preflaring decreases the amount of debris extrusion beyond the apical foramen.

- Randomized clinical trials are required to evaluate the effect of glide path and coronal preflaring on the outcome of root canal treatment.
- The study design of future investigations and manufacturers should consider the appropriate terminology for glide path and preflaring files.

\section{ACKNOWLEDGMENTS}

Gianluca Plotino, Venkateshbabu Nagendrababu, and Hany Mohamed Aly Ahmed contributed equally to this study. The authors deny any conflicts of interest related to this study.

\section{REFERENCES}

1. Ahn SY, Kim HC, Kim E. Kinematic effects of nickel-titanium instruments with reciprocating or continuous rotation motion: a systematic review of in vitro studies. J Endod 2016;42:1009-17.

2. Nagendrababu V, Ahmed HM. Shaping properties and outcomes of nickel-titanium rotary and reciprocation systems using micro-computed tomography: a systematic review. Quintessence Int 2019;50:186-95.

3. Ruddle CJ. Cleaning and shaping root canal systems. In: Cohen S, Burns RC, editors Pathways of the Pulp. 8th ed. St Louis, MO: Mosby; 2002. p. 231-91.

4. Peters OA, Peters $\mathrm{Cl}$. Cleaning and shaping of the root canal system. In: Hargreaves K, Cohen S, editors. Pathways of the Pulp. 11th ed. St. Louis, MO: Mosby; 2011. p. 283-348.

5. Hartmann RC, Peters OA, de Figueiredo JA, Rossi-Fedele G. Association of manual or enginedriven glide path preparation with canal centring and apical transportation: a systematic review. Int Endod J 2018;51:1239-52.

6. Stock CJ, Nehammer CF. Negotiation of obstructed canals; bleaching of teeth. Br Dent $J$ 1985;158:457-62

7. Zuolo ML, Carvalho MC, De-Deus G. Negotiability of second mesiobuccal canals in maxillary molars using a reciprocating system. J Endod 2015;41:1913-7.

8. Plotino G, Ahmed HM, Grande NM, et al. Current assessment of reciprocation in endodontic preparation: a comprehensive review-part II: properties and effectiveness. J Endod 2015;41:1939-50.

9. De-Deus G, Belladonna FG, Souza EM, et al. Scouting ability of 4 pathfinding instruments in moderately curved molar canals. J Endod 2016;42:1540-4.

10. Moher D, Liberati A, Tetzlaff J, et al. Preferred reporting items for systematic reviews and metaanalyses: the PRISMA statement. Ann Intern Med 2009;151:264-9.

11. Augé RM, Toler HD, Saxton AM. Arbuscular mycorrhizal symbiosis alters stomatal conductance of host plants more under drought than under amply watered conditions: a metaanalysis. Mycorrhiza 2015;25:13-24.

12. Sterne JA, Gavaghan D, Egger M. Publication and related bias in meta-analysis: power of statistical tests and prevalence in the literature. J Clin Epidemiol 2000;53:1119-29.

13. Kwak SW, Ha JH, Lee W, et al. Buckling resistance, bending stiffness, and torsional resistance of various instruments for canal exploration and glide path preparation. Restor Dent Endod 2014:39:270-5. 
14. Lopes HP, Elias CN, Mangelli M, et al. Buckling resistance of pathfinding endodontic instruments. J Endod 2012;38:402-4.

15. Lopes HP, Elias CN, Siqueira JF Jr, et al. Mechanical behavior of pathfinding endodontic instruments. J Endod 2012;38:1417-21.

16. Nakagawa RK, Alves JL, Buono VT, Bahia MG. Flexibility and torsional behaviour of rotary nickel-titanium PathFile, RaCe ISO 10, Scout RaCe and stainless steel K-file hand instruments. Int Endod J 2014;47:290-7.

17. Min $Y$, Ma JZ, Shen $Y$, et al. A micro-computed tomography study of the negotiation and anatomical feature in apical root canal of mandibular molars. Scanning 2016;38:819-24.

18. Ahmed HM, Versiani MA, De-Deus G, Dummer PM. A new system for classifying root and root canal morphology. Int Endod J 2017;50:761-70.

19. Mounce RE. Endodontic techniques for scouting the apical thirds of root canals. J Calif Dent Assoc 2006;34:209-12.

20. Plotino G, Grande NM, Porciani PF. Deformation and fracture incidence of Reciproc instruments: a clinical evaluation. Int Endod J 2015;48:199-205.

21. Buchanan LS. Cleaning and shaping the root canal system: negotiating canals to the termini. Dent Today 1994;13:76. 78-81.

22. Kiefner P, Connert T, ElAyouti A, Weiger R. Treatment of calcified root canals in elderly people: a clinical study about the accessibility, the time needed and the outcome with a three-year followup. Gerodontology 2017;34:164-70.

23. Allen MJ, Glickman GN, Griggs JA. Comparative analysis of endodontic pathfinders. J Endod 2007;33:723-6.

24. Görduysus MO, Görduysus M, Friedman S. Operating microscope improves negotiation of second mesiobuccal canals in maxillary molars. J Endod 2001;27:683-6.

25. Hasan M, Raza Khan F. Determination of frequency of the second mesiobuccal canal in the permanent maxillary first molar teeth with magnification loupes (×3.5). Int J Biomed Sci 2014;10:201-7.

26. Karapinar-Kazandag M, Basrani BR, Friedman S. The operating microscope enhances detection and negotiation of accessory mesial canals in mandibular molars. J Endod 2010;36:1289-94.

27. Mertens HW. Comparison of the visual perception of a runway model in pilots and nonpilots during simulated night landing approaches. Aviat Space Environ Med 1978;49:1043-55.

28. West J. The endodontic glidepath: secrets to rotary success. Dent Today 2010;29:90-3.

29. American Association of Endodontists. Glossary of endodontic terms. Available at: https:// www.aae.org/specialty/clinical-resources/glossary-endodontic-terms/; 2015. Accessed July 1 , 2019.

30. Yared G. Canal preparation using only one Ni-Ti rotary instrument: preliminary observations. Int Endod J 2008;41:339-44.

31. Peters OA, Peters Cl, Schönenberger K, Barbakow F. ProTaper rotary root canal preparation: assessment of torque and force in relation to canal anatomy. Int Endod J 2003;36:93-9.

32. Patiño PV, Biedma BM, Liébana CR, et al. The influence of a manual glide path on the separation rate of NiTi rotary instruments. J Endod 2005;31:114-6.

33. Ruddle C, Lamorgese E, Malentacca A, Cotti E. Presentazione della tecnica di preparazione canalare ideata dal. Dr. Clifford Ruddle. G Ital Endod 1998;2:76-81.

34. Roland DD, Andelin WE, Browning DF, et al. The effect of preflaring on the rates of separation for 0.04 taper nickel titanium rotary instruments. J Endod 2002;28:543-5.

35. Tan BT, Messer HH. The effect of instrument type and preflaring on apical file size determination. Int Endod J 2002;35:752-8.

36. Davis RD, Marshall JG, Baumgartner JC. Effect of early coronal flaring on working length change in curved canals using rotary nickel-titanium versus stainless steel instruments. J Endod 2002;28:438-42.

37. Plotino G, Grande NM, Falanga A, et al. Dentine removal in the coronal portion of root canals following two preparation techniques. Int Endod J 2007;40:852-8.

38. Sanfelice CM, Costa FB, Só MV, et al. Effects of four instruments on coronal pre-enlargement by using cone beam computed tomography. J Endod 2010;36:858-61. 
39. Flores CB, Montagner F, Gomes BP, et al. Comparative assessment of the effects of GatesGlidden, Largo, LA-Axxess, and New Brazilian Drill CPdrill on coronal pre-enlargement: conebeam computed tomographic analysis. J Endod 2014;40:571-4.

40. Blum JY, Machtou P, Ruddle C, Micallef JP. Analysis of mechanical preparations in extracted teeth using ProTaper rotary instruments: value of the safety quotient. J Endod 2003;29:567-75.

41. Berutti E, Negro AR, Lendini M, Pasqualini D. Influence of manual preflaring and torque on the failure rate of ProTaper rotary instruments. J Endod 2004;30:228-30.

42. Plotino G, Grande NM, Cordaro M, et al. A review of cyclic fatigue testing of nickel-titanium rotary instruments. J Endod 2009;35:1469-76.

43. Ehrhardt IC, Zuolo ML, Cunha RS, et al. Assessment of the separation incidence of Mtwo files used with preflaring: prospective clinical study. J Endod 2012;38:1078-81.

44. Fogarty TJ, Montgomery S. Effect of preflaring on canal transportation. Evaluation of ultrasonic, sonic, and conventional techniques. Oral Surg Oral Med Oral Pathol 1991;72:345-50.

45. Akhlaghi NM, Bajgiran LM, Naghdi A, et al. The minimum residual root thickness after using ProTaper, RaCe and Gates-Glidden drills: a cone beam computerized tomography study. Eur J Dent 2015;9:228-33.

46. Abou-Rass M, Frank AL, Glick DH. The anticurvature filing method to prepare the curved root canal. J Am Dent Assoc 1980;101:792-4.

47. Isom TL, Marshall JG, Baumgartner JC. Evaluation of root thickness in curved canals after flaring. J Endod 1995;21:368-71.

48. Plotino G, Pameijer $\mathrm{CH}$, Grande NM, Somma F. Ultrasonics in endodontics: a review of the literature. J Endod 2007;33:81-95.

49. Plotino G, Grande NM, Sorci E, et al. A comparison of cyclic fatigue between used and new Mtwo Ni-Ti rotary instruments. Int Endod J 2006;39:716-23.

50. Grande NM, Ahmed HM, Cohen S, et al. Current assessment of reciprocation in endodontic preparation: a comprehensive review - part l: historical perspectives and current applications. J Endod 2015;41:1778-83.

51. Clark D, Khademi J. Modern endodontic access and dentin conservation, part I. Dent Today 2009;28:86-90.

52. Clark D, Khademi J. Modern molar endodontic access and directed dentin conservation. Dent Clin North Am 2010;54:249-73.

53. Clark D. Khademi JA. Case studies in modern molar endodontic access and directed dentin conservation. Dent Clin North Am 2010;54:275-89.

54. Pasqualini D, Scotti N, Tamagnone L, et al. Hand-operated and rotary ProTaper instruments: a comparison of working time and number of rotations in simulated root canals. J Endod 2008;34:314-7.

55. Tepel J, Schäfer E. Endodontic hand instruments: cutting efficiency, instrumentation of curved canals, bending and torsional properties. Endod Dent Traumatol 1997;13:201-10.

56. Schäfer E, Tepel J, Hoppe W. Properties of endodontic hand instruments used in rotary motion. Part 2. Instrumentation of curved canals. J Endod 1995;21:493-7.

57. Esposito PT, Cunningham CJ. A comparison of canal preparation with nickel-titanium and stainless steel instruments. J Endod 1995;21:173-6.

58. Pasqualini D, Bianchi CC, Paolino DS, et al. Computed micro-tomographic evaluation of glide path with nickel-titanium rotary PathFile in maxillary first molars curved canals. J Endod 2012;38:389-93.

59. Paleker F, van der Vyver PJ. Comparison of canal transportation and centering ability of K-files, ProGlider File, and G-Files: a micro-computed tomography study of curved root canals. J Endod 2016;42:1105-9.

60. van der Vyver PJ, Paleker F, Vorster M, de Wet FA. Micro-computed tomographic evaluation of two single rotary glide path systems. Int Endod J 2019;52:352-8.

61. van der Vyver PJ, Paleker F, Vorster M, de Wet FA. Root canal shaping using nickel titanium, m-wire, and gold wire: a micro-computed tomographic comparative study of One Shape, ProTaper Next, and WaveOne Gold instruments in maxillary first molars. J Endod 2019;45:62-7.

62. Vorster M, van der Vyver PJ, Paleker F. Canal transportation and centering ability of waveone gold in combination with and without different glide path techniques. J Endod 2018;44:1430-5. 
63. D'Amario M, Baldi M, Petricca R, et al. Evaluation of a new nickel-titanium system to create the glide path in root canal preparation of curved canals. J Endod 2013;39:1581-4.

64. De Oliveira Alves V, Da Silveira Bueno CE, Cunha RS, et al. Comparison among manual instruments and pathfile and mtwo rotary instruments to create a glide path in the root canal preparation of curved canals. J Endod 2012;38:117-20.

65. Elnaghy AM, Elsaka SE. Evaluation of root canal transportation, centering ratio, and remaining dentin thickness associated with ProTaper Next instruments with and without glide path. $J$ Endod 2014;40:2053-6.

66. Dhingra A, Nagar N, Sapra V. Influence of the glide path on various parameters of root canal prepared with WaveOne reciprocating file using cone beam computed tomography. Dent Res $J$ 2015;12:534-40.

67. de Carvalho GM, Sponchiado Junior EC, Garrido AD, et al. Apical transportation, centering ability, and cleaning effectiveness of reciprocating single-file system associated with different glide path techniques. J Endod 2015;41:2045-9.

68. Uroz-Torres D, González-Rodríguez MP, Ferrer-Luque CM. Effectiveness of a manual glide path on the preparation of curved root canals by using Mtwo rotary instruments. J Endod 2009;35:699-702.

69. Zanette F, Grazziotin-Soares R, Flores ME, et al. Apical root canal transportation and remaining dentin thickness associated with ProTaper Universal with and without PathFile. J Endod 2014;40:688-93.

70. Türker SA, Uzunoğlu E. Apical root canal transportation of different pathfinding systems and their effects on shaping ability of ProTaper Next. J Clin Exp Dent 2015;7:e392-5.

71. Hoppe CB, Böttcher DE, Justo AM, et al. Comparison of curved root canals preparation using reciprocating, continuous and an association of motions. Scanning 2016;38:462-8.

72. Coelho MS, Fontana CE, Kato AS, et al. Effects of glide path on the centering ability and preparation time of two reciprocating instruments. Iran Endod J 2016;11:33-7.

73. Zheng L, Ji X, Li C, et al. Comparison of glide paths created with K-files, PathFiles, and the ProGlider file, and their effects on subsequent WaveOne preparation in curved canals. BMC Oral Health 2018;18:152.

74. Camargo EJ, Duarte MA, Marques VA, et al. The ability of three nickel-titanium mechanized systems to negotiate and shape MB2 canals in extracted maxillary first molars: a microcomputed tomographic study. Int Endod J 2019;52:847-56.

75. Dhingra A, Manchanda N. Modifications in canal anatomy of curved canals of mandibular first molars by two glide path instruments using CBCT. J Clin Diagn Res 2014;8:ZC13-7.

76. Pasqualini D, Alovisi M, Cemenasco A, et al. Micro-computed tomography evaluation of ProTaper Next and BioRace shaping outcomes in maxillary first molar curved canals. J Endod 2015;41:1706-10.

77. Ha JH, Kim SK, Kwak SW, et al. Debris extrusion by glide-path establishing endodontic instruments with different geometries. J Dent Sci 2016;11:136-40.

78. Türker SA, Koçak S, MuratKoçak M, Saglam BC. Effect of glide path preparation on apical debris extrusion of rotary and reciprocating single-file systems: OneShape versus WaveOne. Cumhuriyet Dent J 2015;18:1-8.

79. Topçuoğlu HS, Düzgün S, Akpek F, et al. Influence of a glide path on apical extrusion of debris during canal preparation using single-file systems in curved canals. Int Endod J 2016;49:599-603.

80. Dagna A, El Abed R, Hussain S, et al. Comparison of apical extrusion of intracanal bacteria by various glide-path establishing systems: an in vitro study. Restor Dent Endod 2017;42:316-23.

81. Gunes B, Yesildal Yeter K. Effects of different glide path files on apical debris extrusion in curved root canals. J Endod 2018;44:1191-4.

82. Pawar AM, Pawar M, Kfir A, et al. Effect of glide path preparation on apical extrusion of debris in root canals instrumented with three single-file systems: an ex vivo comparative study. J Conserv Dent 2017;20:110-4.

83. Caviedes-Bucheli J, Castellanos F, Vasquez N, et al. The influence of two reciprocating single-file and two rotary-file systems on the apical extrusion of debris and its biological relationship with symptomatic apical periodontitis. A systematic review and meta-analysis. Int Endod J 2016;49:255-70. 
84. Ustun Y, Aslan T, Sagsen B, Kesim B. The effects of different nickel-titanium instruments on dentinal microcrack formations during root canal preparation. Eur J Dent 2015;9:41-6.

85. De-Deus G, Cesar de Azevedo Carvalhal J, Belladonna FG, et al. Dentinal microcrack development after canal preparation: a longitudinal in situ micro-computed tomography study using a cadaver model. J Endod 2017;43:1553-8.

86. Saber SE, Schäfer E. Incidence of dentinal defects after preparation of severely curved root canals using the Reciproc single-file system with and without prior creation of a glide path. Int Endod J 2016;49:1057-64.

87. Türker SA, Uzunoğlu E. Influence of a glide path on the dentinal crack formation of ProTaper Next system. Restor Dent Endod 2015;40:286-9.

88. Bürklein S, Werneke M, Schäfer E. Impact of glide path preparation on the incidence of dentinal defects after preparation of severely curved root canals. Quintessence Int 2018;49:607-13.

89. Topçuoğlu HS, Düzgün S, Akpek F, Topçuoğlu G. Effect of glide path and apical preparation size on the incidence of apical crack during the canal preparation using Reciproc, WaveOne, and ProTaper Next systems in curved root canals: a stereomicroscope study. Scanning 2016;38:585-90.

90. Kfir A, Goldberger T, Koren T, et al. Can size 20, .04 taper rotary files reproducibly create a glide path for the self-adjusting file? An ex vivo study in MB canals of mandibular molars. Int Endod $\mathrm{J}$ 2016;49:301-6.

91. De-Deus G, Cavalcante DM, Belladonna FG, et al. Root dentinal microcracks: a post-extraction experimental phenomenon? Int Endod J 2019;52:857-65.

92. Paleker F, van der Vyver PJ. Glide path enlargement of mandibular molar canals by Using Kfiles, the ProGlider File, and G-Files: a comparative study of the preparation times. J Endod 2017:43:609-12.

93. Kirchhoff AL, Chu R, Mello I, et al. Glide Path management with single- and multiple-instrument rotary systems in curved canals: a micro-computed tomographic study. J Endod 2015;41:1880-3.

94. Alovisi M, Cemenasco A, Mancini L, et al. Micro-CT evaluation of several glide path techniques and ProTaper Next shaping outcomes in maxillary first molar curved canals. Int Endod $J$ 2017;50:387-97.

95. Vorster M, van der Vyver PJ, Paleker F. Influence of glide path preparation on the canal shaping times of WaveOne Gold in curved mandibular molar canals. J Endod 2018;44:853-5.

96. Kim Y, Love R, George R. Surface changes of PathFile after glide path preparation: an ex vivo and in vivo study. J Endod 2017;43:1674-8.

97. Zarrabi MH, Javidi M, Vatanpour M, Esmaeili H. The influence of torque and manual glide path on the defect or separation rate of NiTi rotary instruments in root canal therapy. Indian J Dent Res 2010;21:107-11.

98. Türker SA, Sağlam BC, Koçak MM, Koçak S. The effect of glide path on the surface quality of new and used rotary and reciprocating single files: OneShape versus WaveOne. Scanning 2014;36:608-13.

99. Patel D, Bashetty K, Srirekha A, et al. Scanning electron microscopic evaluation of the influence of manual and mechanical glide path on the surface of nickel-titanium rotary instruments in moderately curved root canals: an in-vivo study. J Conserv Dent 2016;19:549-54.

100. Özyürek T, Uslu G, Yılmaz K, Gündoğar M. Effect of glide path creating on cyclic fatigue resistance of Reciproc and Reciproc Blue nickel-titanium files: a laboratory study. J Endod 2018;44:1033-7.

101. Arias A, De Vasconcelos RA, Hernández A, Peters OA. Torsional performance of ProTaper Gold rotary instruments during shaping of small root canals after 2 different glide path preparations. J Endod 2017;43:447-51.

102. Arias A, Singh R, Peters OA. Differences in torsional performance of single- and multipleinstrument rotary systems for glide path preparation. Odontology 2016;104:192-8.

103. Sathorn C, Parashos P, Messer H. The prevalence of postoperative pain and flare-up in singleand multiple-visit endodontic treatment: a systematic review. Int Endod J 2008;41:91-9.

104. Pasqualini D, Mollo L, Scotti N, et al. Postoperative pain after manual and mechanical glide path: a randomized clinical trial. J Endod 2012;38:32-6. 
105. Keskin C, Sivas Yilmaz Ö, Inan U, Özdemir Ö. Postoperative pain after glide path preparation using manual, reciprocating and continuous rotary instruments: a randomized clinical trial. Int Endod J 2019;52:579-87.

106. De-Deus G, Arruda TE, Souza EM, et al. The ability of the Reciproc R25 instrument to reach the full root canal working length without a glide path. Int Endod J 2013;46:993-8.

107. Adiguzel M, Tufenkci P. Comparison of the ability of Reciproc and Reciproc Blue instruments to reach the full working length with or without glide path preparation. Restor Dent Endod 2018;43:e41.

108. Rodrigues E, De-Deus G, Souza E, Silva EJ. Safe mechanical preparation with reciprocation movement without glide path creation: result from a pool of 673 root canals. Braz Dent $J$ 2016;27:22-7.

109. Plotino G, Grande NM, Testarelli L, Gambarini G. Cyclic fatigue of Reciproc and WaveOne reciprocating instruments. Int Endod J 2012;45:614-8.

110. Plotino G, Giansiracusa Rubini A, Grande NM, et al. Cutting efficiency of Reciproc and waveOne reciprocating instruments. J Endod 2014;40:1228-30.

111. Higuera $\mathrm{O}$, Plotino G, Tocci L, et al. Cyclic fatigue resistance of 3 different nickel-titanium reciprocating instruments in artificial canals. J Endod 2015;41:913-5.

112. Bartols A, Robra B, Walther W. The ability of Reciproc instruments to reach full working length without glide path preparation: a clinical retrospective study. PeerJ 2017;5:e3583.

113. Saini HR, Tewari S, Sangwan $P$, et al. Effect of different apical preparation sizes on outcome of primary endodontic treatment: a randomized controlled trial. J Endod 2012;38:1309-15.

114. Grossmann LI, Oliet S, Del Rio CE. Preparation of the root canal: equipment and technique for cleaning, shaping and irrigation. Endod Pract 1988;11:179-227.

115. Tennert C, Herbert J, Altenburger MJ, Wrbas KT. The effect of cervical preflaring using different rotary nickel-titanium systems on the accuracy of apical file size determination. J Endod 2010;36:1669-72.

116. Pecora JD, Capelli A, Guerisoli DM, et al. Influence of cervical preflaring on apical file size determination. Int Endod J 2005;38:430-5.

117. Stabholz A, Rotstein I, Torabinejad M. Effect of preflaring on tactile detection of the apical constriction. J Endod 1995;21:92-4.

118. Vanni JR, Santos R, Limongi $O$, et al. Influence of cervical preflaring on determination of apical file size in maxillary molars: SEM analysis. Braz Dent J 2005;16:181-6.

119. Barroso JM, Guerisoli DM, Capelli A, et al. Influence of cervical preflaring on determination of apical file size in maxillary premolars: SEM analysis. Braz Dent J 2005;16:30-4.

120. Ibelli GS, Barroso JM, Capelli A, et al. Influence of cervical preflaring on apical file size determination in maxillary lateral incisors. Braz Dent J 2007;18:102-6.

121. Souza RA, Sousa YT, de Figueiredo JA, et al. Influence of apical foramen lateral opening and file size on cemental canal instrumentation. Braz Dent J 2012;23:122-6.

122. Sharma SA, Tyagi SP, Sinha DJ, et al. Influence of cervical preflaring using different rotary instruments on the accuracy of apical file size determination: a comparative in-vitro study. J Conserv Dent 2014;17:575-8.

123. Schmitz Mda S, Santos R, Capelli A, et al. Influence of cervical preflaring on determination of apical file size in mandibular molars: SEM analysis. Braz Dent J 2008;19:245-51.

124. Ashwini TS, Bhandari S. The influence of cervical preflaring of root canal on determination of initial apical file using Gates Glidden drills, Protaper, Race and diamond-coated Galaxy files. J Contemp Dent Pract 2012;13:554-8.

125. Silveira LF, Martos J, Pintado LS, et al. Early flaring and crown-down shaping influences the first file bind to the canal apical third. Oral Surg Oral Med Oral Pathol Oral Radiol Endod 2008; 106:e99-101.

126. Silveira LF, Silveira CF, Castro LA, et al. Crown-down preflaring in the determination of the first apical file. Braz Oral Res 2010;24:153-7.

127. Khan IU, Sobhi MB. Detecting the apical constriction in curved mandibular molar roots-preflared versus nonflared canals. J Ayub Med Coll Abbottabad 2003;15:47-9.

128. labal A, Akbar I, AL-Omiri MK. An in vivo study to determine the effects of early preflaring on the working length in curved mesial canals of mandibular molars. J Contemp Dent Pract 2013;14:163-7. 
129. Kumar R, Khambete N, Patil S, et al. Working length changes in curved canals after coronal flaring by using rotary files and hand file: an in vitro study. J Conserv Dent 2013;16:399-403.

130. Schroeder KP, Walton RE, Rivera EM. Straight line access and coronal flaring: effect on canal length. J Endod 2002;28:474-6.

131. Fallahdoost A, Namazikhah MS, Sheikholeslaami M, Tavakkoli K. Effect of preflaring on working length determination: an in vivo study. J Calif Dent Assoc 2008;36:951-3.

132. Ibarrola JL, Chapman BL, Howard JH, et al. Effect of preflaring on Root ZX apex locators. J Endod 1999;25:625-6.

133. de Camargo EJ, Zapata RO, Medeiros PL, et al. Influence of preflaring on the accuracy of length determination with four electronic apex locators. J Endod 2009;35:1300-2.

134. Brito-Júnior M, Camilo CC, Moreira-Júnior G, et al. Effect of pre-flaring and file size on the accuracy of two electronic apex locators. J Appl Oral Sci 2012;20:538-43.

135. de Moor RJ, Hommez GM, Martens LC, De Boever JG. Accuracy of four electronic apex locators: an in vitro evaluation. Endod Dent Traumatol 1999;15:77-82.

136. Coelho MS, Card SJ, Tawil PZ. Visualization enhancement of dentinal defects by using lightemitting diode transillumination. J Endod 2016;42:1110-3.

137. Coelho MS, Card SJ, Tawil PZ. Light-emitting diode assessment of dentinal defects after root canal preparation with Profile, TRUShape, and WaveOne Gold systems. J Endod 2016;42:1393-6.

138. Kim HC, Sung SY, Ha JH, et al. Stress generation during self-adjusting file movement: minimally invasive instrumentation. J Endod 2013;39:1572-5.

139. Arslan H, Karataş E, Capar ID, et al. Effect of ProTaper Universal, Endoflare, Revo-S, HyFlex coronal flaring instruments, and Gates Glidden drills on crack formation. J Endod 2014;40:1681-3.

140. Wilcox LR, Roskelley $C$, Sutton $T$. The relationship of root canal enlargement to finger-spreader induced vertical root fracture. J Endod 1997;23:533-4.

141. Borges ÁH, Damião MS, Pereira TM, et al. Influence of cervical preflaring on the incidence of root dentin defects. J Endod 2018;44:286-91.

142. Duarte MA, Bernardes RA, Ordinola-Zapata R, et al. Effects of Gates-Glidden, LA Axxess and orifice shaper burs on the cervical dentin thickness and root canal area of mandibular molars. Braz Dent J 2011;22:28-31.

143. Wu M-K, van der Sluis LW, Wesselink PR. The risk of furcal perforation in mandibular molars using Gates-Glidden drills with anticurvature pressure. Oral Surg Oral Med Oral Pathol Oral Radiol Endod 2005;99:378-82.

144. Homayoon A, Hamidi MR, Haddadi A, et al. Comparing the coronal flaring efficacy of five different instruments using cone-beam computed tomography. Iran Endod J 2015;10:263-7.

145. Setzer FC, Böhme CP. Influence of combined cyclic fatigue and torsional stress on the fracture point of nickel-titanium rotary instruments. J Endod 2013;39:133-7.

146. Maniglia-Ferreira C, de Almeida Gomes F, Ximenes T, et al. Influence of reuse and cervical preflaring on the fracture strength of reciprocating instruments. Eur J Dent 2017;11:41-7.

147. Swindle RB, Neaverth EJ, Pantera EA Jr, Ringle RD. Effect of coronal-radicular flaring on apical transportation. J Endod 1991;17:147-9.

148. Heard F, Walton RE. Scanning electron microscope study comparing four root canal preparation techniques in small curved canals. Int Endod J 1997;30:323-31.

149. Sinan A, Georgelin-Gurgel M, Diemer F. Evaluation of the preparation of the coronal part of the mesial canals of lower molars. Odontostomatol Trop 2011;34:13-9.

150. Barbieri N, Leonardi DP, Baechtold MS. Influence of cervical preflaring on apical transportation in curved root canals instrumented by reciprocating file systems. BMC Oral Health 2015;15:149.

151. Bürklein S, Benten S, Schäfer E. Quantitative evaluation of apically extruded debris with different single-file systems: Reciproc, F360 and OneShape versus Mtwo. Int Endod J 2014;47:405-9.

152. Topçuoğlu HS, Üstün Y, Akpek F, et al. Effect of coronal flaring on apical extrusion of debris during root canal instrumentation using single-file systems. Int Endod J 2016;49:884-9. 
153. Borges ÁH, Pereira TM, Porto AN, et al. The influence of cervical preflaring on the amount of apically extruded debris after root canal preparation using different instrumentation systems. J Endod 2016;42:465-9.

154. Somma F, Leoni D, Plotino G, et al. Root canal morphology of the mesiobuccal root of maxillary first molars: a micro-computed tomographic analysis. Int Endod J 2009;42:165-74.

155. Sujith R, Dhananjaya K, Chaurasia VR, et al. Microscope magnification and ultrasonic precision guidance for location and negotiation of second mesiobuccal canal: an in vivo study. J Int Soc Prevent Communit Dent 2014;4:S209-12.

156. Plotino G, Grande NM, Pecci R, et al. Three-dimensional imaging using microcomputed tomography for studying tooth macromorphology. J Am Dent Assoc 2006;137:1555-61.

157. Özyürek T, Uslu G, Gündoğar M, et al. Comparison of cyclic fatigue resistance and bending properties of two reciprocating nickel-titanium glide path files. Int Endod J 2018;51:1047-52.

158. Yılmaz K, Uslu G, Gündoğar M, et al. Cyclic fatigue resistances of several nickel-titanium glide path rotary and reciprocating instruments at body temperature. Int Endod J 2018;51:924-30.

159. Plotino G, Cortese T, Grande NM, et al. New technologies to improve root canal disinfection. Braz Dent J 2016;27:3-8. 